\title{
SUPPORTING ORGANIZATIONS
}

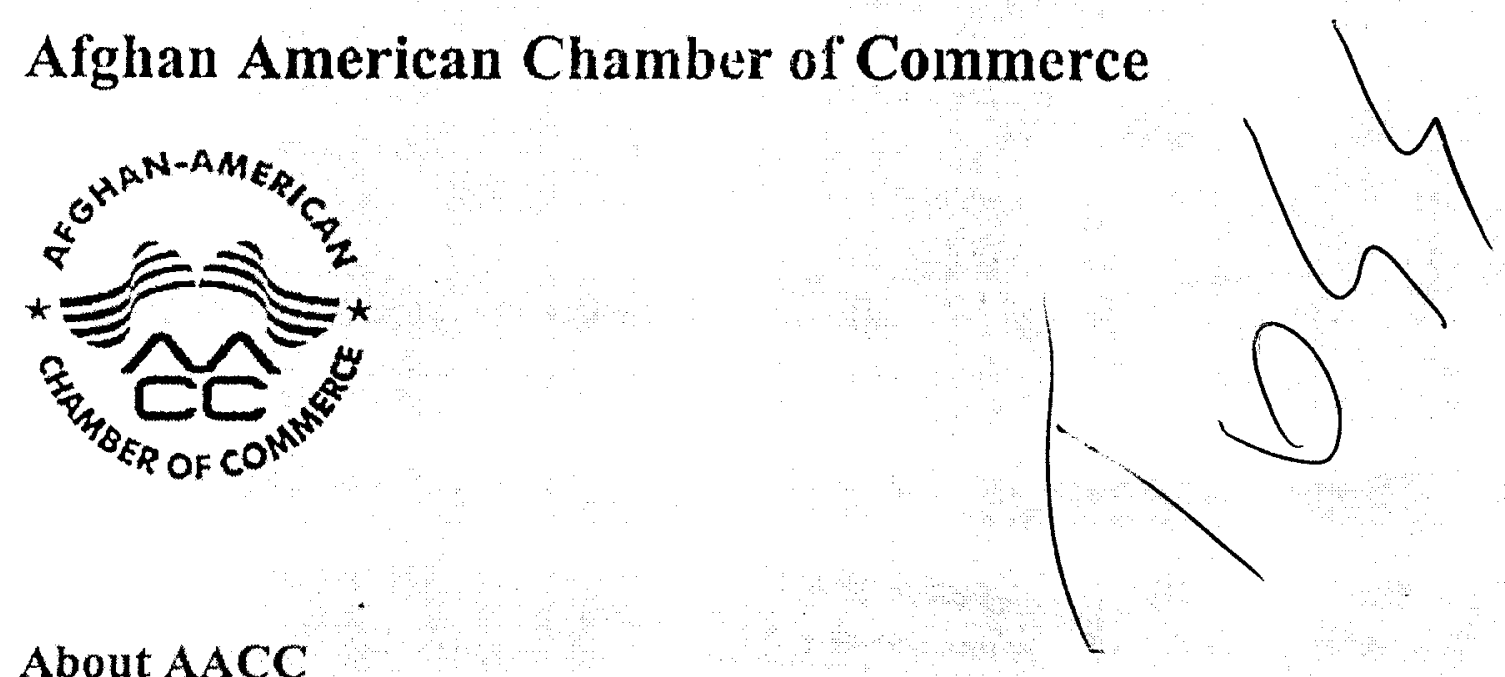

The Afghan-American Chamber of Commerce (AACC) was fomed in 2002 to promote openmarket economy and Afghan-American businesses in Afghanistan.

As Afghanistan moves to establish a democratic system and open-market econony, it is important to ensure that the rules of the system are open and fair for all. In a nutshell, this is the mission of AACC. By forming partnerships with business associations, think tanks, universities, local chambers of commerce, and other business organizations that have vested interests in an open economy and a democratic political system, AACC will launch its activities inside Afghanistan to accomplish its mission.

\section{American Council of Engineering Companies}

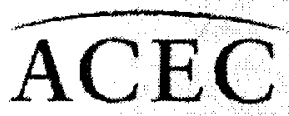

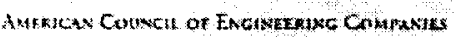

The American Council of Engineering Companies (ACEC) is the voice of America's engineering industry. Council members - numbering more than 5,800 firms throughout the country - are engaged in a wide range of engineering works that propel the nation's economy, and enthance and safeguard America's quality of life. These works allow Americans to drink elean water, enjoy a healthy life, take advantage of new technologies, and travel safely and efficiently. The Council's 


\section{SUPPORTING ORGANIZATIONS}

\section{Afghan American Chamber of Commerce}
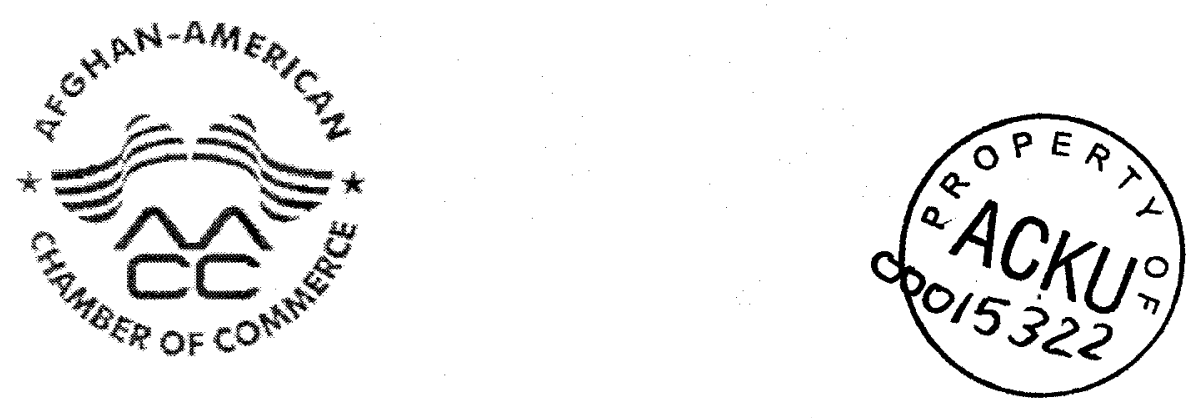

\section{About AACC}

The Afghan-American Chamber of Commerce (ACC) was formed in 2002 to promote openmaket economy and Afghan-American businesses in Afghanistan.

As Afghauistan moves to establish a democratic system and open-market conomy, it is important to ensure that the rules of the system are open and fair for all. In a nutshel, this is the mission of A ACC. By forming partmerships with business associations, think tanks, universities, local chanbers of commerce, and other business organizations that have vested interests in an open economy and a democratic political system, AAC will launch its activities inside Afghanistan to accomplish its mission.

\section{American Council of Engineering Companies}

\section{$\widehat{\mathrm{ACEC}}$}

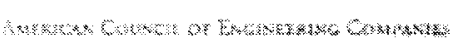

The American Council of Engineering Companies (ACEC) is the voice of America's engineering industry. Council members - numbering more than 5,800 firms throughout the country - ar engaged in a wide range of engincering works that propel the nation's economy, and enhance and safeguard Arrerteds quality of lite. These works allow Americans to dnak clean water enjoy a healthy life, take advantage of new technologies, and travel safely and efficiently. The Council's 


\section{Electric Power Supply Association}

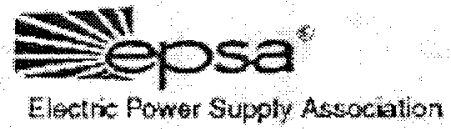

FPSA's mission is 10 advance the interests of its members: conpetitive generators, power marketers and other suppliers. EPSA advocates domestic and international policies that will result in a fully competitive electric power supply marketplace. EPSA supports the development of a market in which existing commitments such as independent power contracts are honored and in which all customers have a choice of electric suppliers by a date certain.

EPSA is the national trade association representing competitive power suppliers, including independent power producers, merchant generators and power marketers. These suppliers, who account for more than a third of the nation's installed generating capacity, provide reliable and competitively priced electricity fom environmentally responsible facilities serving global power markets. EPSA seeks to bring the benefits of competition to all power customers.

Formed as a result of a merger between the National Independent Energy Producets and the Electric Generation Association, EPSA combines the strengths and policy successes of those wo prominent organizations on behalf of the competitive power supply industry. EPSA's formation has given the competitive power supply industry the ability to speak with a single, unified voice at the global and national levels.

As the debate continues in the U.S. Congress, federal regulatory agencies, and state capitals around the country, EPSA advocates policies and positions that allow its member companies to compete aggressively for the privilege of serving electricity consumers. EPSA is confident that, as it has in other industries, such competition will bring lower prices, and more and better services for electricity customers. As such, the association will continue to play a constructive role in the intensifying congressional and regulatory debate about how to create an efficient national power market for all customers. Working in concert with the industry's state and regional associations, EPSA also participates in precedent setting regulatory and legisiative procedings in the states.

As the association's membership roster demonstrates, EPSA members include many of the premier companies involved in the generation and marketing of electricity. Today's power suppliers face complex technological, enwironmental, and risk management challenges. EPSA members are responsible for some of the most innovative solutions to these challenges. Those solutions have resulted in more efficient generating technologies that have driven down the cost of producing electricity; cost-ffective environmental solutions that have resulted in significantly 
exchange of views on international business, economic policy, trade and investment issues between members and senior U.S. and foreign govemment officials and international business leaders. The Committee's membership includes more than 100 major multinational corporations in Chicago and the Midwest. Committee activities are planned to facilitate Chicago's contimuing development as a global trading and financial center.

\section{The Society of Afghan Engineers}

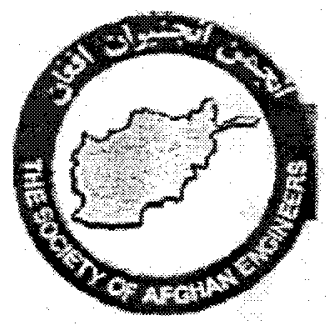

The Society of Afghan Engineers is a private nonprofit and nonpolitical corporation whose purpose is to foster international support and to encourage financial and technical assistance for the reconstruction and prosperity of Afghanistan. This Society was formed in 1993 by a group of Afghan engineers in Northem Virginia and surrounding areas who believe that they have a moral responsibility to help the grief-stricken people of Afghanistan.

\section{United States Energy Association}

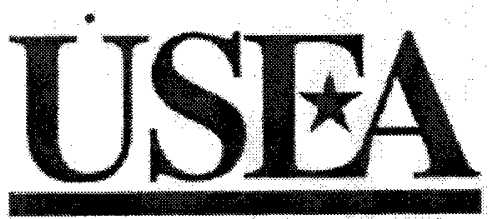

United States Energy Association

The United States Energy Association (USEA) is the U.S. Member Committee of the World Energy Council (WEC). USEA is an association of public and private energy-related organizations, corporations, and government agencies. USEA represents the broad interests of the U.S. energy sector by increasing the understanding of energy issues, both domestically and internationally.

USEA coordinates participation of the United States in the WEC by nominating representatives 10 WEC activities, organizes the U.S. delegation to the triennial WEC Congress, WEC Executive 


\section{Banking in Afghanistan}

\section{IFC's Support for a Viable Financial Sector}

Peer Stein

June 10,2003

\section{Needs and Challenges of the Financial Sector}

- Needs:

- Facilitating money flows and providing financial products for the reconstruction of Afghanistan

- Financing and deposit-taking for the economically active population, in particular micro and small businesses

- Challenges:

- Lack of legal framework, e.g. no banking law

- Infrastructure, security and human resources

-. Stable currency

- Money-laundering

- Lack of corporate sector on SOEs 


\section{IFC's Initial Support: Creation of First Microfinance Bank of Afghanistan (FMBA)}

- Create licensed microfinance bank to provide both credit and savings services to micro and small businesses

- Develop nationwide branch nerwork over three to five years time horizon

- Initial focus: Urban and semi-urban, with potential links for further outreach with AKF programs

- Additional services: Basic banking services for NGOs, UN, multilateral and bilateral organizations and other institutional clients (model: Microbank BosniaHerzegowina)

\section{Capitalization, ownership \& technical assistance}

- Initial capital: US\$4 million (pending)

- Initial shareholders: AKFED and IFC

- Future shareholders: KW, possibly ADE and ING

- Technical assistance package required for first three years

- Higher TA funding needs than usual, due to particularly difficult environment (security, money laundering \& currency issues, social aspects e.g. addressing child labor, financing women etc.) 


\section{IFC's future role}

- Provide advice and technical assistance, 0.9 .

- banking

- leasing

- insurance

- housing mance

- Invest in new institutions and fnance existing ones (e.g. credit lines. trade facilities) as maket evolves 


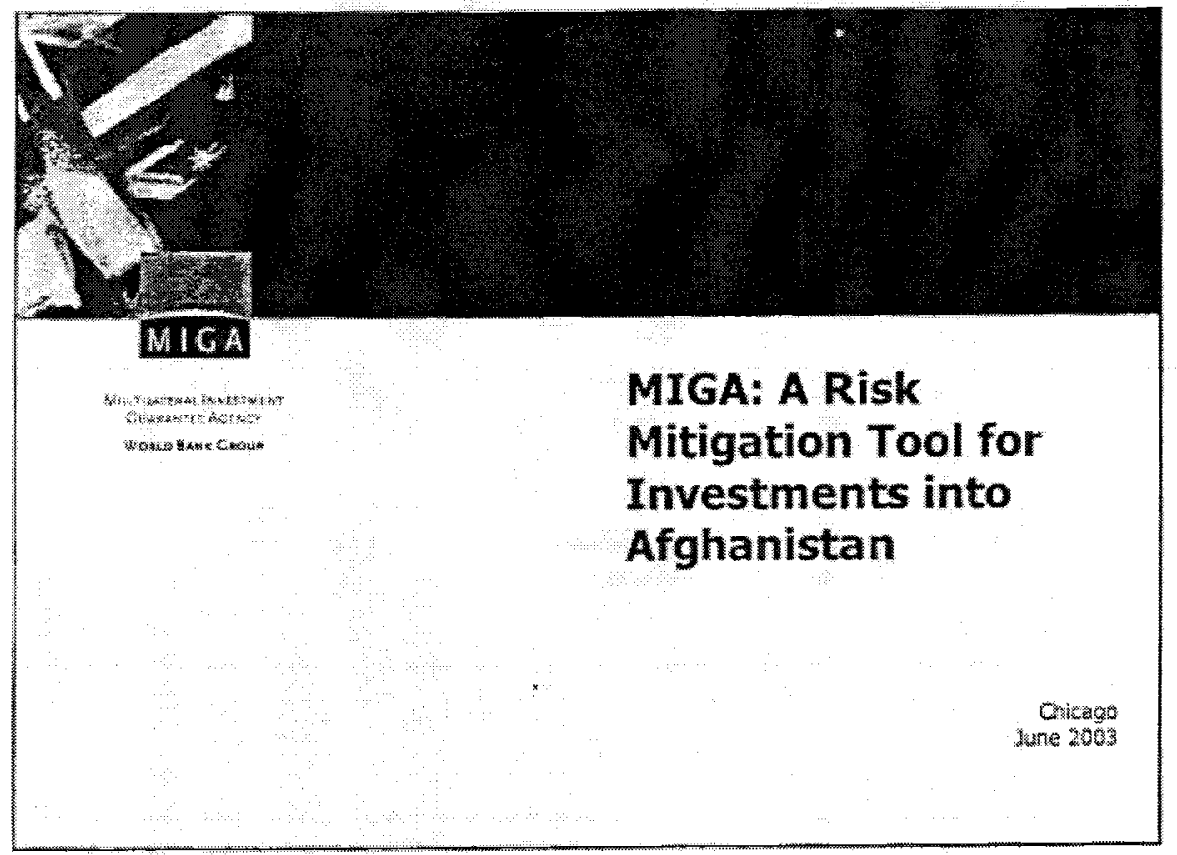

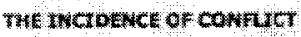

\section{Post-conflict situations}

As a development instututon, contict is on the forefront of MGAs agenda:

* In the 11-year post-cold war period ( $900^{\prime}$ oo) there were 56 different major armed conflicts in 44 different locations

- In po here were 25 major amed conflicts in 23 locations

* Arrica and Asta continue 10 be the regions with the greatest number of confilets .

- Al of the conflicts in 2000 were internal but also splled over into neighboring states, and concerned control over the govermment or teritory

* Most ongoing conflics have proved difficult to end, whth the majority having lasted seven years or more 


\section{FWo ANo}

\section{Risks faced by investors in conflict-affected countries}

* Threa of resumption of war and political violence (business interrugtion)

- Rule of law not established (weak judiciary, potential political interference) and governments not able to enforce rule of law

- Low levels of foreign exchange

... all resulting in a poor business environment

\section{Fon ANo risks}

\section{Concerns of investors investing in Afghanistan}

- Currency transfer restriction and inconvertibility

- Expropriation

* War and civil disturbance

- Breach of contract 


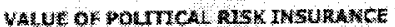

\section{Value Proposition for Host Countries}

- Technology transfer

- Management skils

- Tax revenues

- Re-establishment of trade/supplier relations that were lost during the war

- Local jobs and procurement.

- Encouraging environmentally and socially responsible investments

- Economic growth

\section{MIGA's experience to date}

- Approximately $11 \%$ of the portolio in conflict. affected countries

- Projects supported in (Algeria),Angola, Azerbaijan, Bosnia-Herzegovina, Croata, Georgia, Guatemala, Macedonia, Nepal, Sri Lanka

- EU Inwestment Guarantee Trust Fund for BosnieHerzegovina

- Mutim donor guarantee trust fund for West Bank and Gazd - one project 


\section{Trust Fund for Afghanistan}

\section{Rationale:}

- Risks. Trust Fund allows MIGA to share risks with donors in absence of private insurer interest, leading to a more immediate and full deployment of guarantee products

- Fexibilty: Allows MIGA to adapt its guarantee product to the needs of Afghamistan by insuring mports of capital goods vital or reconstuction (agricuture, heatin)

- Timing: Fall of 2003 


\section{Oil and Gas Sector}

\section{Projects}

- Sheberghan to Kabul Gas Pipeline and Generating Plant

(Ministry of Mines and Industries)

\section{Sheberghan to Kabul Gas Pipeline and Generating Plant}

\section{Project Outline}

The Ministry of Mines and Industries (MMI) would like to expand the supply of power to the city of Kabul with new generating capacity based on donestic natural gas reserves.

This would reguire the constuction of a new generating facility located either at the gas fields near Sheberghan in the north, or in Kabul.

If the new generating facility were to be located in Kabul, it would be necessary to construct a 300 -mile gas pipeline between Sheberghan and Kabul. 


\section{Sheberghan to Kabul Gas Pipeline and Generating Plant Project Financing}

The total estrmated project cost is 5333 millon.

The vort Bank has recently approved a $\$ 3$ millon grate for Emetgency Infrastrueture Recontruedon in Afghanistan. This loan has ar oil and gas commonent.

Throwgh the grant, the World Bank plans to furd policy-10late

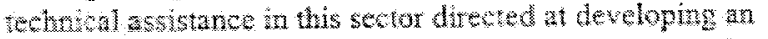

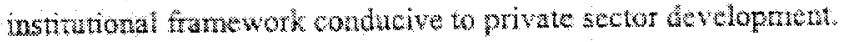


Afghanistan Ministry of Mines and Industry and U.S. Geological Survey Cooperative Oil and Gas Resource Assessment for Afghanistan

$$
\begin{aligned}
& \text { World Energy Project } \\
& \text { U.S. Geological Survey } \\
& \text { June, } 2003
\end{aligned}
$$

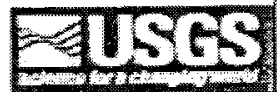

\section{USGS Mission:}

- Provide unbiased scientific information and analyses to the government, the public and industry

- The information is used by Policy makers, citizens, and industry to make informed decisions about the preservation, use, and development of natural resources. 


\section{Elements Required to Produce a Widely Accepted and Endorsed Assessment:}

- Comprehensive Methodology

- Reproducible Results

- Transparent Process

- Qualifed Independent Geologic Team

- Experienced Assessors

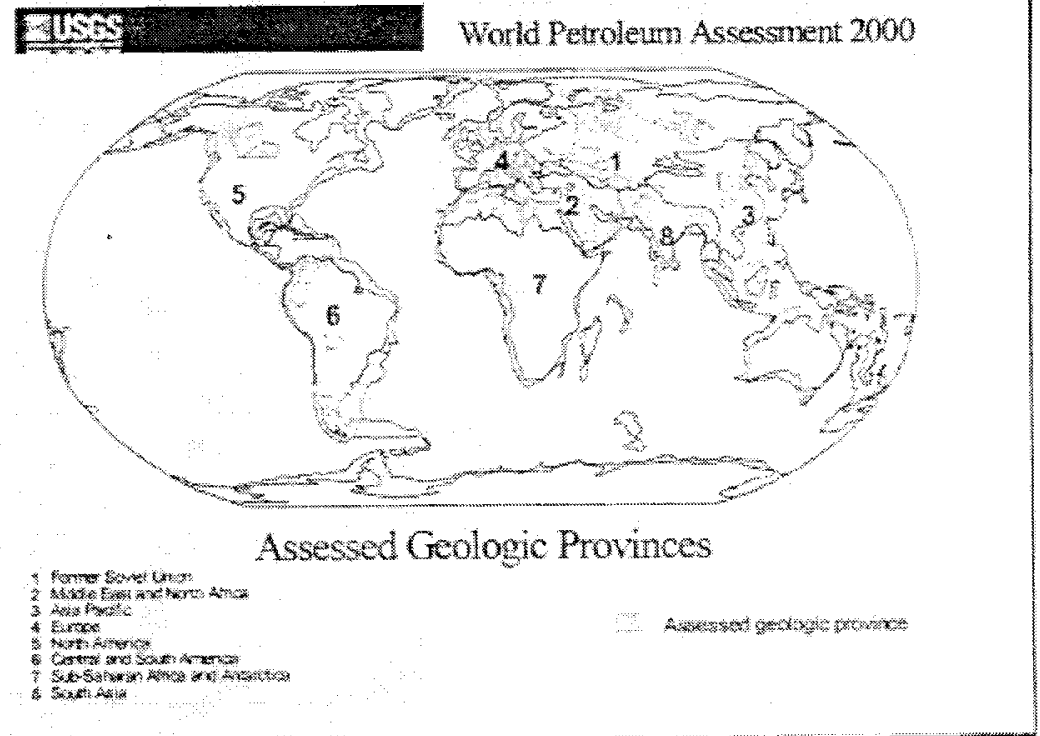




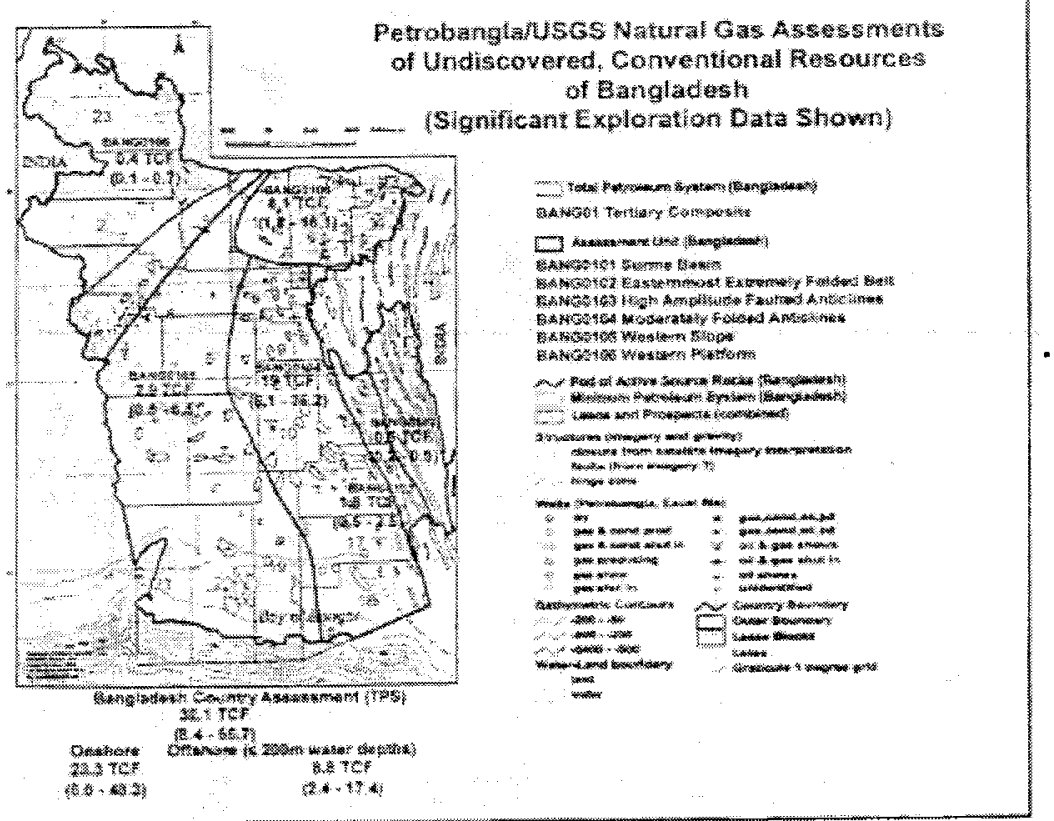

Assesmon Isstas:

\section{Areas to be Assessed}

- Northern Afghanistan Holds the Greatest Opportunity for Near Term Development

- Assessments of Other Blocks with Potential will be Prioritized 

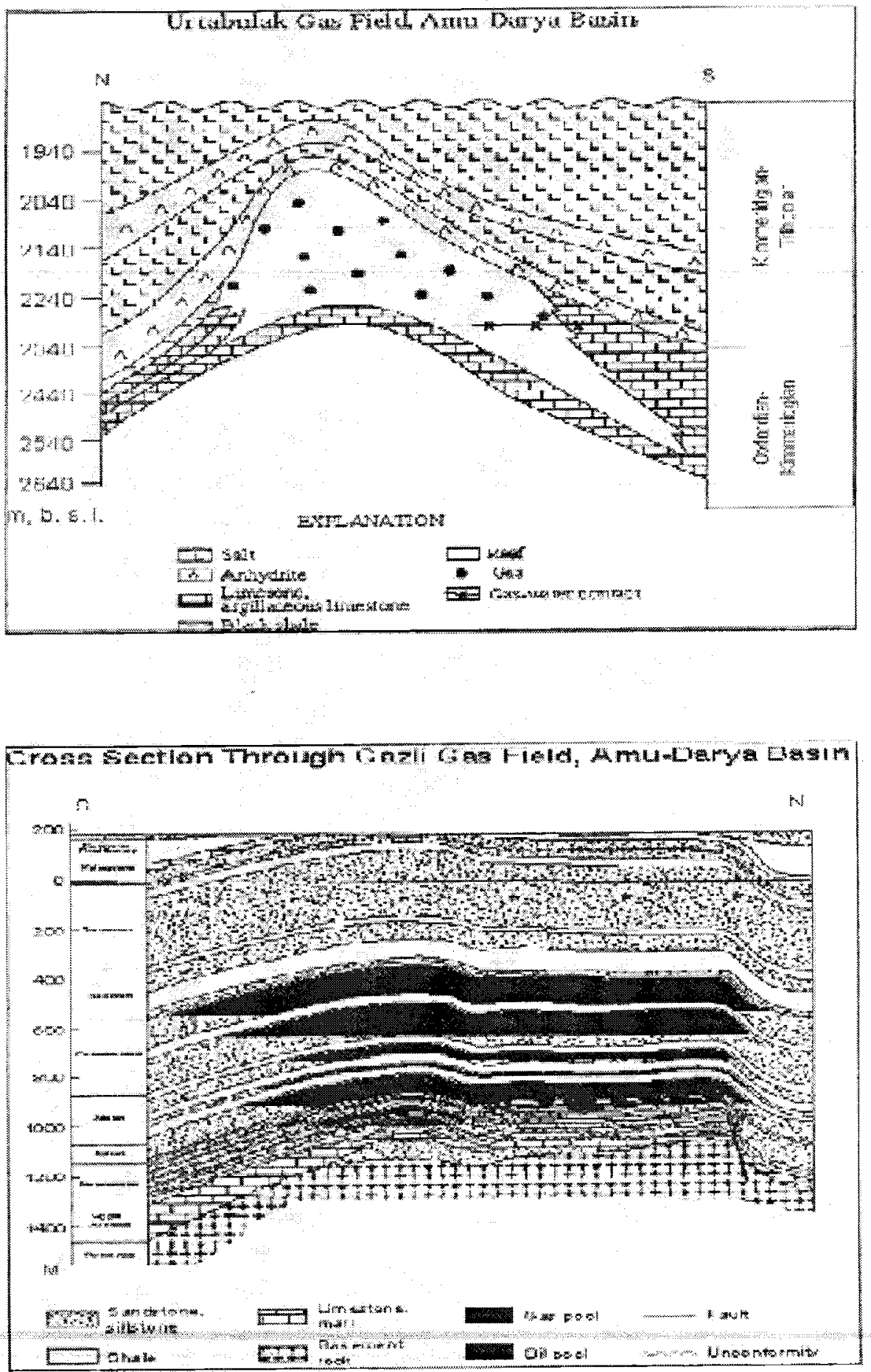


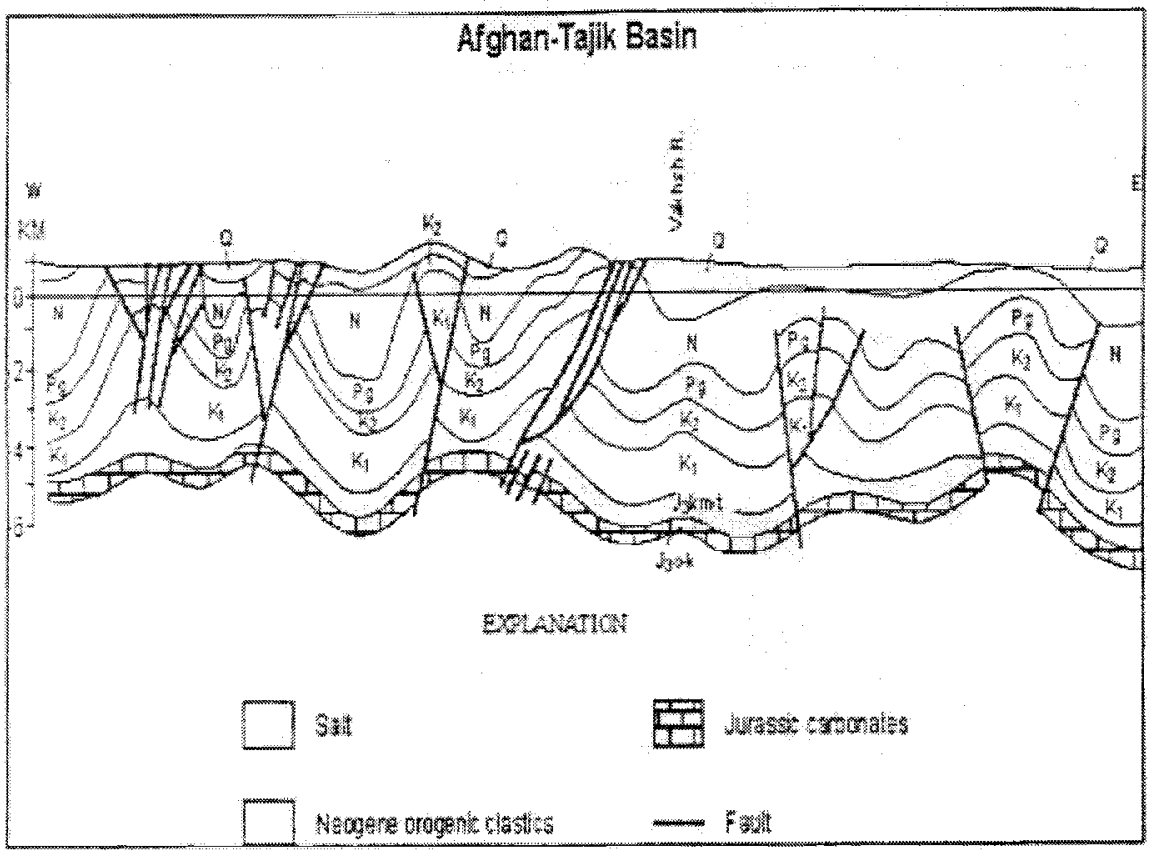

\section{Summary}

I. Collect and inventory existing oil and gas resource data

II. Analyze existing oil and gas resources data

nu. Define petroleum systems and exploration plays

IV. Conduct assessments of undiscovered oil and gas resources

v. Disseminate assessment results 


\section{Transport Sector \\ Projects}

- Kabul Airport Navigation Aid Rehabilitation (Ministry of Civil Aviation and Tourism)

- Kabul-Doshi Road \& Salang Tunnel Rehabilitation Project (Ministry of Public Wotks)

Kabul Airport Navigation Aid Rehabilitation

\section{Project Outline}

Afghanistan has 22 airports with two major gateways:

Kabul Intemational Airport, and

- Kandahar Intemational Airport.

There are five smaller domestic airports:

$>$ Mazar-e-Sharif,

- Herat,

Y Talalabad,

$>$ Kunduz, and

- Chakcharan. 


\section{Kabul Airport Navigation Aid Rehabilitation}

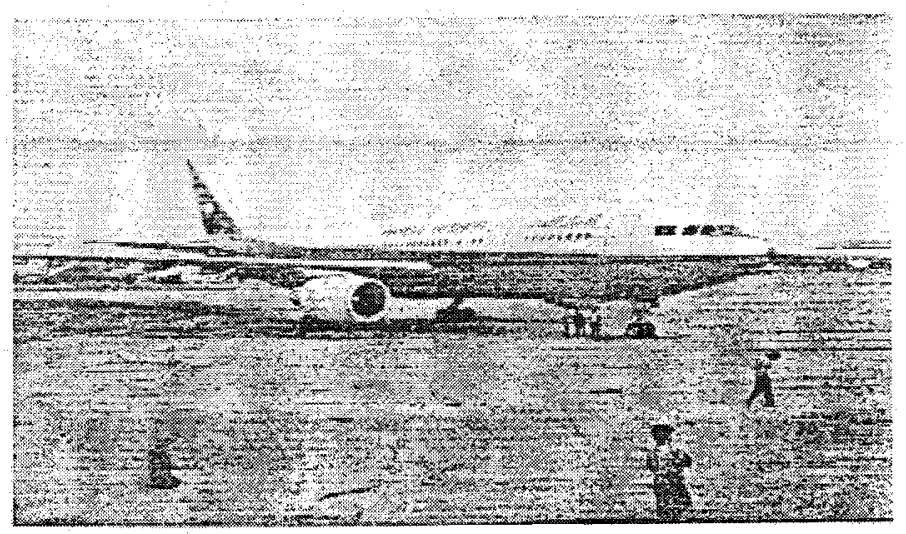

\section{Kabul Airport Navigation Aid Rehabilitation}

\section{Technical Description}

The World Bank has approved funding to provide communication and air traffic control equipment for the Kabul International Airport to upgrade it to international standards.

The linancing will mainly encompass safety and security equipment costs including:

- Vorading be communication system and radio navigation aids.

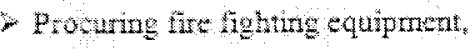

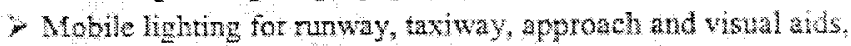

- Neteorologiea equipnent,

Grand harding equandent and 
- ADB follows a three-pronged

approach for postconflict

reconstruction

- ADB focuses:

- Building capital;

- Rehabilitating production and income especially for the poor; and

- Building capacity to improve aid absorption.

\section{Political Events}

In Afghanistan, the international community has witnessed:

- Removal of the Taliban from power;

- Signing of a power-sharing agreement by representatives of the major Afghan factions in Bonn in December 2001; 
- A Constitutional Loya Jirga is scheduled for October 2003 and national elections for June 2004

\section{The Economy}

- GDP per capita estimated at $\$ 167$ in 2002 at current prices

- Macroeconomic picture is improving

- Agricultural production especially wheat production projected well above than previous year

- Small construction boom is underway in secure areas like Kabul 


\section{The Cost of Reconstruction}

A comprehensive needs assessment conducted by the ADB, UNDP and WB assessed between $\$ 14.6$ billion and $\$ 18.1$ billion over a 10 year period:

\begin{tabular}{|l|c|c|c|c|}
\hline Scenario & \multicolumn{4}{|c|}{ USs millon } \\
& 1 year & 2.5 years & 5 years & 10 years \\
\hline Base Cost & 1,700 & 4,500 & 10,200 & 14,600 \\
\hline Low Cost & 1,400 & 4,200 & 8,300 & 11,400 \\
\hline High Cost & 2,100 & 6,500 & 12,200 & 18,100 \\
\hline
\end{tabular}

During the International

Conference on Reconstruction

Assistance in Tokyo on 21-22 January

2002 (Tokyo Conference), donors

pledged $\$ 4.5$ billion for a 2.5 year

period from 2002 to 2004.

An amount of about $\$ 1.8$ billion

was actually disbursed in 2002 . 
- During the ASG annual meeting in Oslo in December 2002, the Government of Afghanistan laid out its plans to move towards the consultation group structure that would replace the ARSG and the ASG leading to the first Afghanistan Development Forum (ADF) held on 13-14 March in Kabul followed by a high-level strategic forum in Brussels on 17-18 March.

\section{Afghanistan Reconstruction Trust Fund (ARTF)}

- Set up in May 2002, has channeled the assistance of 22 donors and has emerged as one of the main instruments for financing the country's recurrent budget.

- Evolving into a significant financing source for the Government's investment programs and technical assistance. 
Kabul Airport Navigation Aid Rehabilitation

\section{Equipment \& Services (cont.)}

The project will procure the following equipment:

- Air Traffic Control (ATC) Equipment -ATCConsoles, Radar Data Recorder, VHF Direction Finder, Radar Data Display System, Telegraph equipment, Voice Communication system, Voice Recorder and modernization of existing radar installations;

- Airfeld Landing Aids-Precision Approach RWY highting, RWY lighting System, TWY Lighting System, Non-Precision Approach Lighting system, PAPI and Emergency Power source;

Navigational equipment--.nstrument Landing System and Non Directional Beacons (NDB); and

Kabul Airport Navigation Aid Rehabilitation Project Financing

The project will be financed by a World Bank International Development Assistance loan for $\$ 19.3$ million. This loan is part of an overall Emergency Transportation Rehabilitation loan which was approved in January 2003. 


\section{Kunduz Khanabad Irrigation System Project Site}

The Kunduz Khanabad Irrigation System is located 29 kilometers to the east of Kunduz, in Northern Afghanistan. The main canal runs 18 kilometers from east to west, into the outskirts of Kunduz town.

\section{Project Status/Timeline}

The status of the project is dormant. Any timeline for reconstruction will be driven by the financing agency.

\section{Kunduz Khanabad Irrigation System}

\section{Equipment \& Services}

\section{The following equipment and services are needed to complete the project:}

- Electrica components and mechanical cutpment for raising and lowering the sted curtans;

- Eectica trussmission lines for bringing etectricity to the strex.

- Earth movinglexcavation equpment for cand dredging. and

- Possble computer controlled fow meterng systems and usage netering equinment. 


\section{Kunduz Khanabad Irrigation System}

\section{Project Financing}

Total project cost is estimated at $\$ 25$ millon.

Presently, there is no financing available to the Ministry of Irrigation

The Government of India funded a complete technical assessment of the Kundwz Khanabad Irrigation system during October and November of 2002. The firm that carried out this assessment was WapCOS, the original designers of the World Bank funded project. 


\section{Private Sector Development}

- Seen by the Government:

- as the engine of growth of the economy

- as the medium to creating an environment conducive to private sector growth

The Government's initiatives to promote private sector investment include:

- New investment law

- Opening up the telecom sector for the private sector

- Removal of export taxes

- Established a consultative forum with merchants 
- In infrastructure, sector reforms, supported by the Program include:

- separation of operational and regulatory functions of sector institutions,

- establishing regulatory frameworks that give the private sector comfort to operate and invest, and

- introduction of procurement guidelines, regulations and documentation in accordance with international standards.

- Through ADB's infrastructure investment projects, international and local contractors will be directly involved in reconstruction activities. 


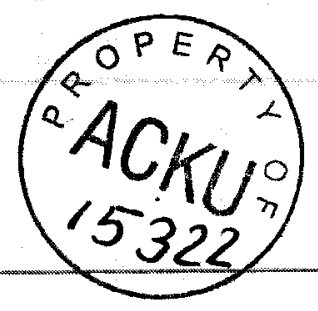

- Postconflict Multisector Program for $\$ 150$ million approved in 2002.

- \$100 million was disbursed in 2002

- $\$ 50$ million to be disbursed in 2003

- \$37 million in grants

- Country Strategy and Program Update for 2003-2005 was approved by the Board in June 2003 committing $\$ 610$ million:

- $\$ 580$ million in concessional loans from the ADF

- \$30 million in technical assistance grants 
For 2003:

- Total requirement is $\$ 200$ million:

- \$190 million in ADF, and

- \$10 million in technical assistance grants

- Emergency Infrastructure Rehabilitation and Reconstruction Project in an amount of $\$ 150$ million (approved 3 June 2003) as the most important assistance activity for the year.

The Project envisages to rehabilitate and reconstruct:

- $447 \mathrm{~km}$ of primary national road network including the link to Uzbekistan

- Power transmission lines in the northern provinces and the distribution system in Kabul,

- damaged gas production, transmission, and distribution facilities in Sheberghan, including the natural gas pipeline to Mazar-i-Sharif. 
- In transport, Central Asian Republics are looking for road access to the Arabian Sea through Afghanistan, Iran and Pakistan - combined with streamlining of customs and border procedures would foster regional trade.

The possibilities of regional energy trade include:

- Export power from Uzbekistan into Afghanistan;

- Resumption of export gas from Afghanistan; and

- Export of gas from Turkmenistan to India via Afghanistan and Pakistan 


\section{Security}

- Overall security situation remains tenuous.

- The north and west of the country are relatively safe; the south and east continues to be of high security risk areas.

- ADB security considerations in project sites, especially for transport and energy projects will determine the pace at which these can be implemented. 
- External financing commitment in particular for the ARTF are insufficient to finance the recurrent budget requirement.

- Financing the development budget is also encountering problems:

- current level of contributions to the ARTF does not allow financing of investment projects.

- only a small proportion of the projects in the development budget have been committed to donors 
As the civil society representation urged the donors during the first Afghanistan Development Forum:

We want you to look at Afghanistan differently as you have before. Just because some of us are conservative, wear long beards, turbans and traditional clothes, does not mean that we do not want a better future for our children (boys and girls)...

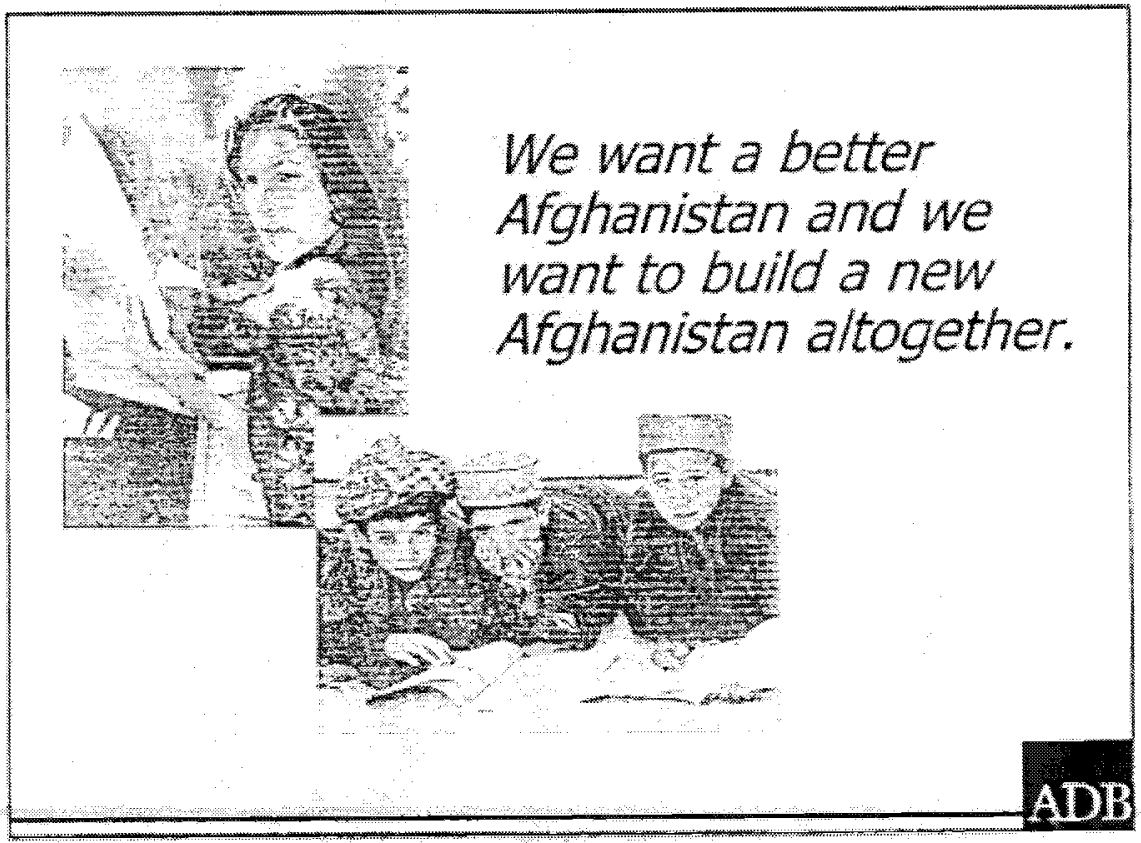




\section{ADB Operations}

\section{in \\ Afghanistan}

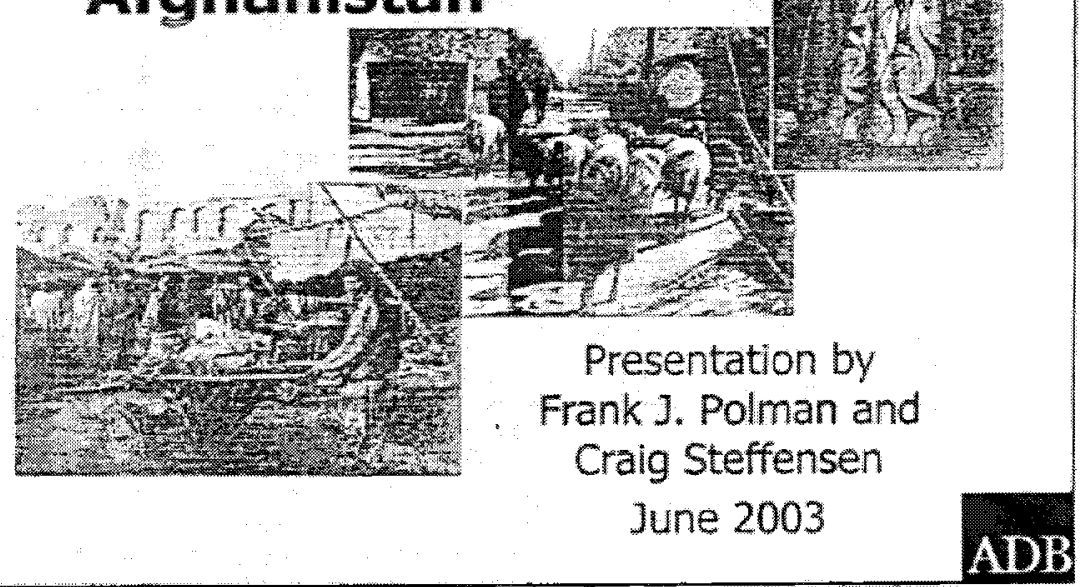

\section{ADB in Afghanistan}

- Assumed a key role since September 2001 in the international community's efforts to assist in Afghanistan's reconstruction.

- Drawn its experience in providing postconflict assistance for rehabilitation and reconstruction to Cambodia East Timor, and Tajikistan. 


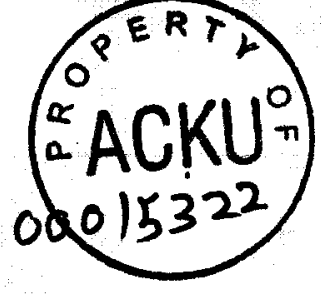

- \$350 million from donor financing

- Donors have pledged so far $\$ 116$ million for the recurrent budget, leaving a \$234 million gap.

- Funding the $2003 / 2004$ development budget will require $\$ 1.72$ billion, to be financed by donors through:

- direct program support

- contributions to the ARTF investment window

- direct contracting of projects in consultation with the Government. 
- They help countries rebuild its institutions, formulate policies and establish sustainable systems of government.

- ADB, IsDB, WB and IMF have been directly involved in assisting reconstruction.

- ADB and WB (with UNDP)

- undertook a comprehensive needs assessment that constituted the basis for donor pledges in the Tokyo Conference

- provided technical assistance for initial capacity building and institutional support to the Afghanistan administration 


\section{Afghanistan's Energy Void:}

Impact, Threats and Opportunities

U.S. Trate and Develomment Agency

Aighanistan: Rebuilding a Hation Conference

June 9.2003

William L Polen, United States Energy Association

\section{Afghanistan Energy Working Group}

- Established January 2002

- Members: General Electric, Bechtel, Gaterpillar, Siemens Westinghouse, Black \& Veatch, Bearing Point, Cummins, K\& Engineering, Nexant, USG Participation

- Conducted US TDA Sponsored oV for Minister of Water \& Power in Dec. 2002 


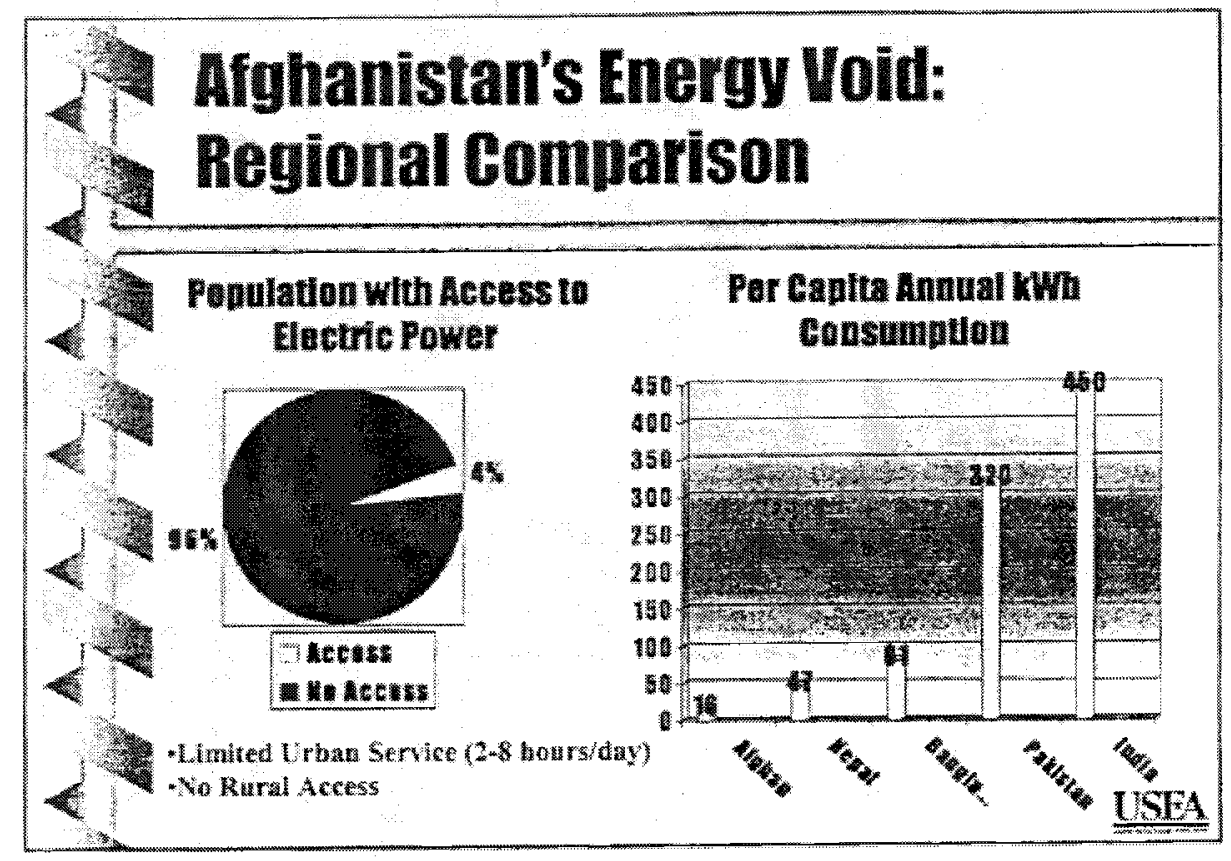

\section{Power Sector Infrastructure Cannot Produce \& Deliver}

$<$

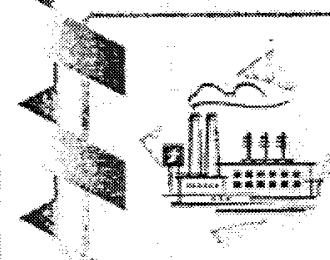

Genceration

$23 \mathrm{~km}$

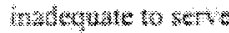

$2 \mathrm{smp}$ populatign

Agring

intrastrwcture

requitres

rehabiltatusen

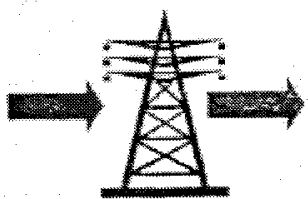

Tramsruission

Contus Delver

5 Wh of

Lines Dostroyed

$50 \%$

Tranxomer

Capacty

Deatroyed

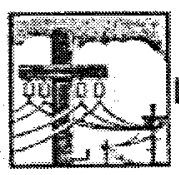

Distribution

Cammet beblyes:

Over Hot of Uriat

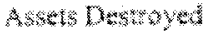

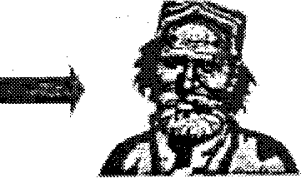

2 million +

Yopulation

30000 condections

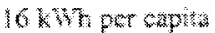
consumption

DDP inctedsing detrutud

USEA 


\section{Ministry of Water \& Power}

Enterprises and Departments

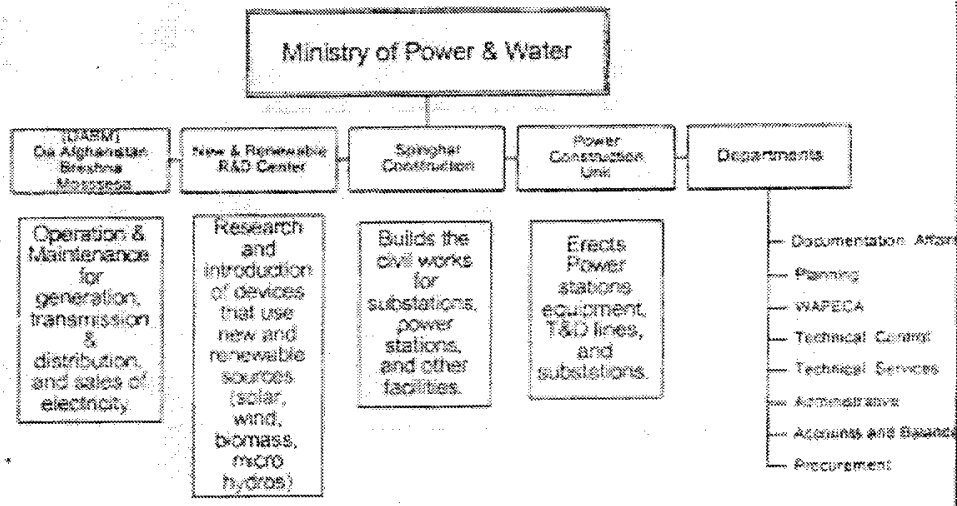

\section{Sector Policy}

Electricity is the backbone to any economic recovery.

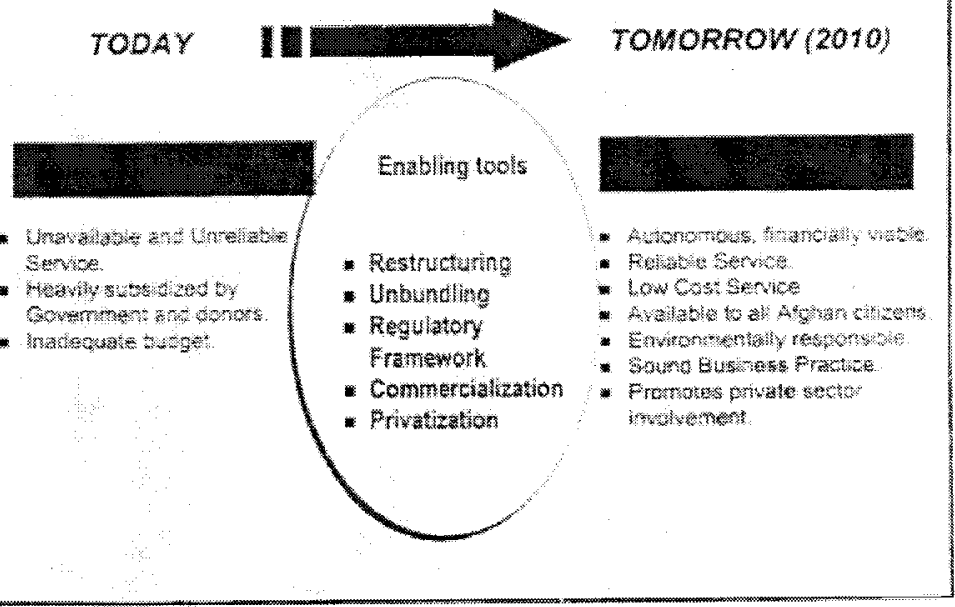


Secondary Cities Emergency Power Project

\section{Proiect Outline}

The World Bank funded Secondary Cities Emergency Power Project is designed to improve infrastructure facilities and delivery and lay the foundations for sector reforms and institution bulding.

In addition to the creation of suitable legal and regulatory frameworks, capacity building efforts supported by the project would help to create absorptive capacty for handling donor assistance.

\section{Secondary Cities Emergency Power Project Technical Description}

The proposed grant will finance the most urgent reconstruction and technical assistance requirements in the urban infrastructure and energy sub-sectors.

The Power component of the proposed project would consist of the following five parts:

Transmission and Distribution Materials (US\$6.5 million equivalent)

Essential Tools and Equipment (US\$1.5 million equiralent)

Hydropower Station Repairs (USS2.5 million equivalent)

Recommissioning of NW Kabul Gas Turbine Plant 
Secondary Cities Emergency Power Project

\section{Project Financing}

The total estimated project cost is $\$ 15$ million.

Contracts will be financed through the World Bank. They will be subject to the World Bank's procurement policies and rules, and will be open to firms from any World Bank country. 


\section{National and International Satellite Network Installation Project Outline}

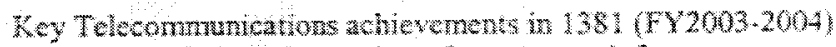
inchude completion of a wather of emerency infrastucture projects; cstablishment of a prolininary plicy framework and dewelopnent plan: private sector invertment of around SUSD16.4m, moderriwation of internal Minstry of Communicutons management ystres, and identifeation and commenceraent of a range of investment project to suppont the rebuiding of the Telcommunication yub sector.

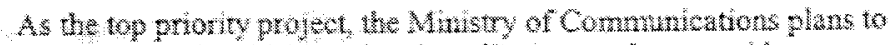

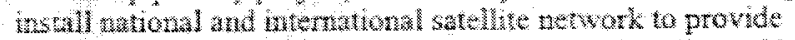

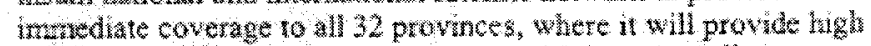
capacty communications (voles, dats and hiternet) to all areas crimper when eath station facintics.

\section{National and International Satellite Network Installation Technical Description}

The new network will provide common infrastructure that can be used by all sector and govemment departments including bankmg, merior, education, mining health, etc as well as cstablsh infrastructure framework for postal tele coners and a natonal postal bank. This rew system will be versatile cnough to also distrbute telovison programming rationally.

This project is essentil becuse curenty, were is no mational backbone, connecivity or platorm to manage intematona call traffe in Afganistan, and there are no communication services hroughout most of the country. 
National and International Satellite Network Installation

\section{Equipment \& Services}

The following equipment is required for this project:

- Hub, back-up hub, and infrastructure;

Satellite access points in "tice 1" cities"

$>$ Satellite access points in "tier 2 " cities;

- Satellite access points for 200 other smaller destinations;

- Intemational gateway switch router;

- Tele centers (public phones and internet) structures;

- Network Operations Center; and

$P$ Ondains onerations maintenance and training

National and International Satellite Network Installation

\section{Project Financing}

The total project cost, as per Ministry of Communications estimates, is $\$ 5.55$ million.

No funding source has been identified yet but funding is anticipated from the World Bank or other donors. 
Kabul-Doshi Road \& Salang Tunnel Rehabilitation Project

\section{Project Outline}

The proposed Project will:

- Suppont the rehabilitation of the existing Kabul-

Doshi and the Doshi-Pol-e-Khomri-Kunduz Road atong its current aligument,

Finance equipment and training related to winter road maintenance in the Salang area, and

Finance necessary Technical Assistance to establish permanent self-financing arrangements for road mamtenance and operation of the Salang tunnel and mountain roads from toad users.

Kabul-Doshi Road \& Salang Tumel Rehabilitation Project

\section{Technical Description}

The Highway Rehabilitation will focus on restoring the road to its former state rather than on improving the standards of the road, except sections which are likely to be elevated to avoid flooding.

The Secondary and Tertiary Roads component under the program will finance the rehabilitation of selected secondary and tertiary roads serving tural populations in the area of influetce of the main road comidor being rehabilitated under the Project. Two secondary roads have been pre-identified by the Government for inclusion:

Talaqan-Faizabad Section of the Kunduz - Faizabad 


\section{Kabul-Doshi Road \& Salang Tunnel Rehabilitation Project Equipment \& Services}

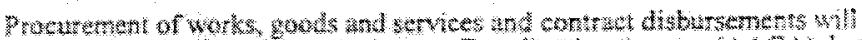
be dow mow

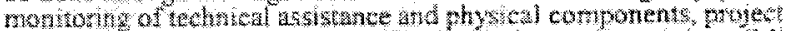

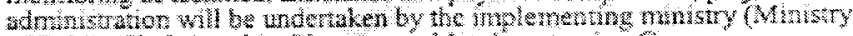

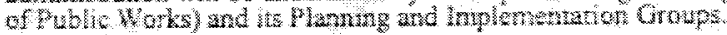

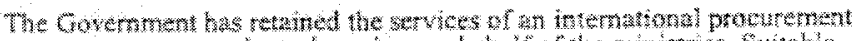

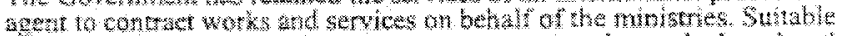

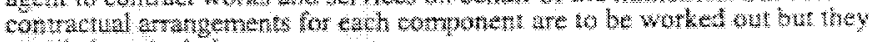

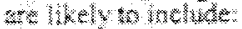

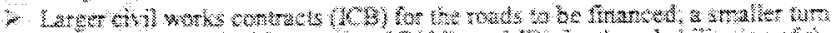

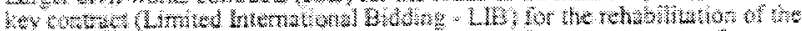

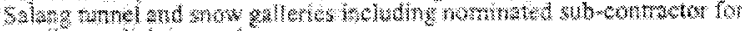
wern

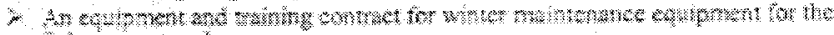

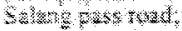

2. Amaty

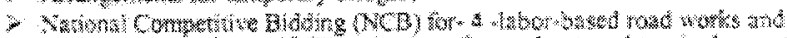
Guatry

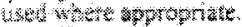

\section{Kabul-Dosh Road \& Salang Tunnel Rehabilitation Project Equipment \& Services (cont.)}

The road rehabilitation projects will require the following equipment and services:

sexprescos

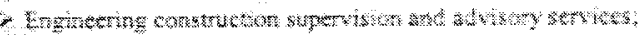

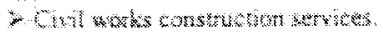

wax

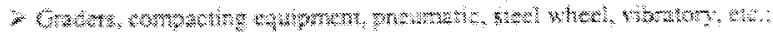

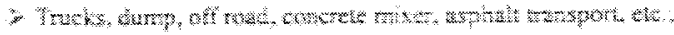

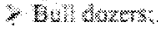

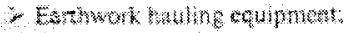

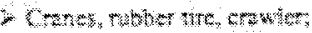

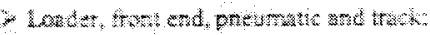

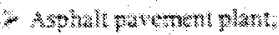

Amall pares:

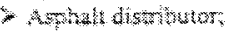

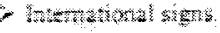




\section{The 2002 Program}

- Set stage for resuming operations in 2002 with the approval of the Initial Country Strategy and Program (ICSP) 2002-2004

- committed $\$ 500$ million in loans and grants for reconstruction of social and physical infrastructure, revitalizing agriculture, private sector development and capacity building

- Approved in 2002 total of $\$ 187$ million:

- \$15 million technical assistance grants,

- \$22 million grant financed projects,

- \$150 million Postconflict Multisector Program loan (after DFID provided $\$ 18$ million to clear arrears with ADB) 
TA Cluster (TAC) of $\$ 14.5$ million for Capacity Building for Reconstruction and Development

- strengthens the ability of various government ministries and departments to formulate policies and plans and implement projects in various sectors

- 40 consulting contracts currently under implementation

- $\$ 500,000$ grant for TA for Capacity Building for Disaster Preparedness and Management

- helps Afghanistan's Office of

Disaster Preparedness become a credible coordination agency for disaster management and focal point for multi-disaster issues 
- Kuwait Fund approved additional $\$ 15$ million cofinancing grant in May 2003

- to further improve road including remaining $42 \mathrm{~km}$, gravelling and paving of shoulders and asphalt overlay over the entire road

- Community-Based Basic Education for the Poor Project for $\$ 4$ million.

- The objective is to:

(i) increase access to and improve quality of basic education for children in poor communities, and

(ii) explore and pilot test mechanism for effective partnerships between the Government, schools, NGOs and communities in development and implementation of innovative basic education services 


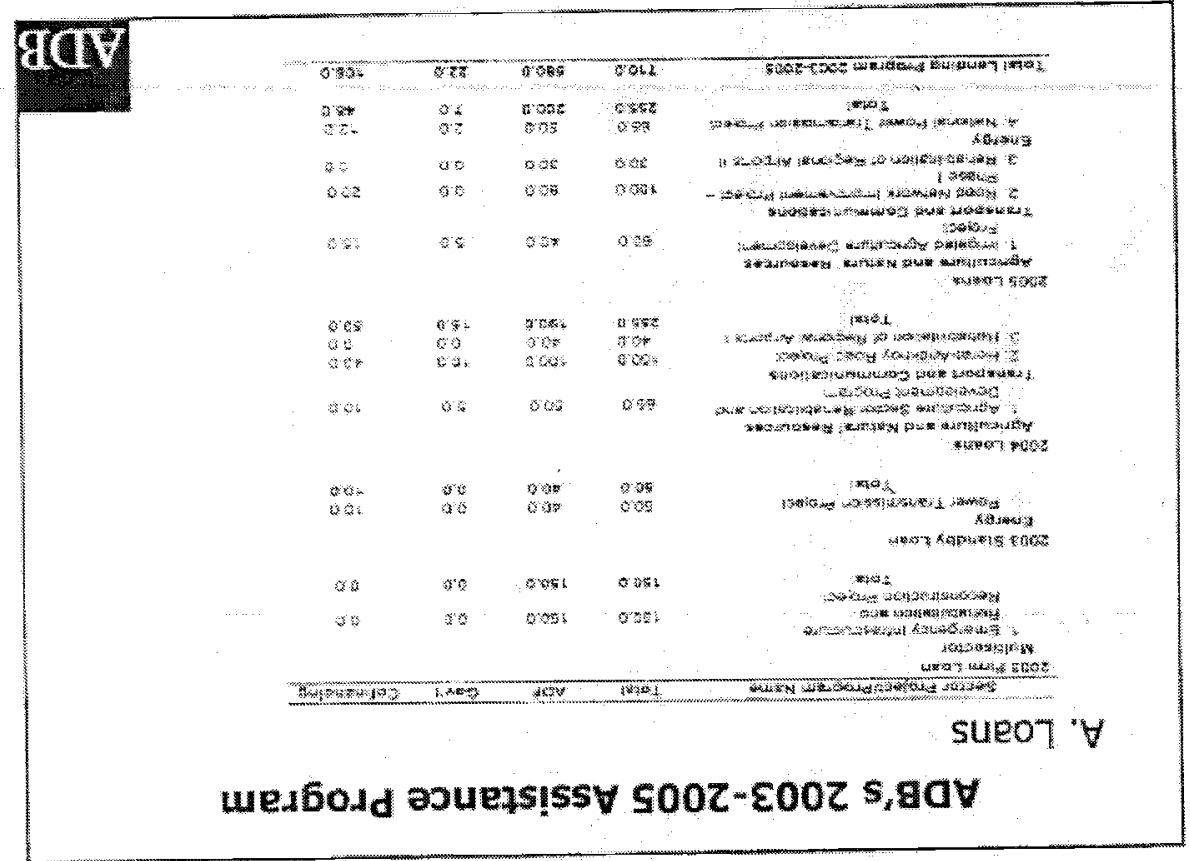

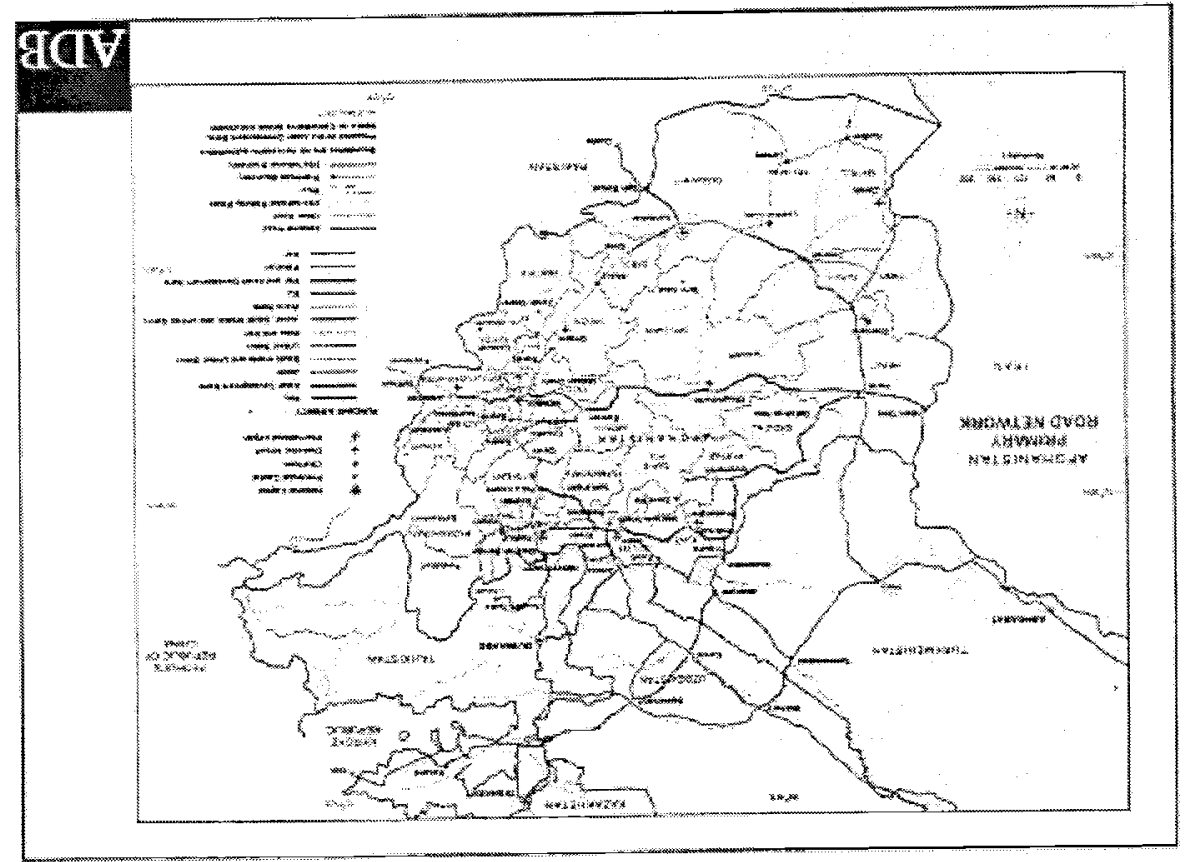




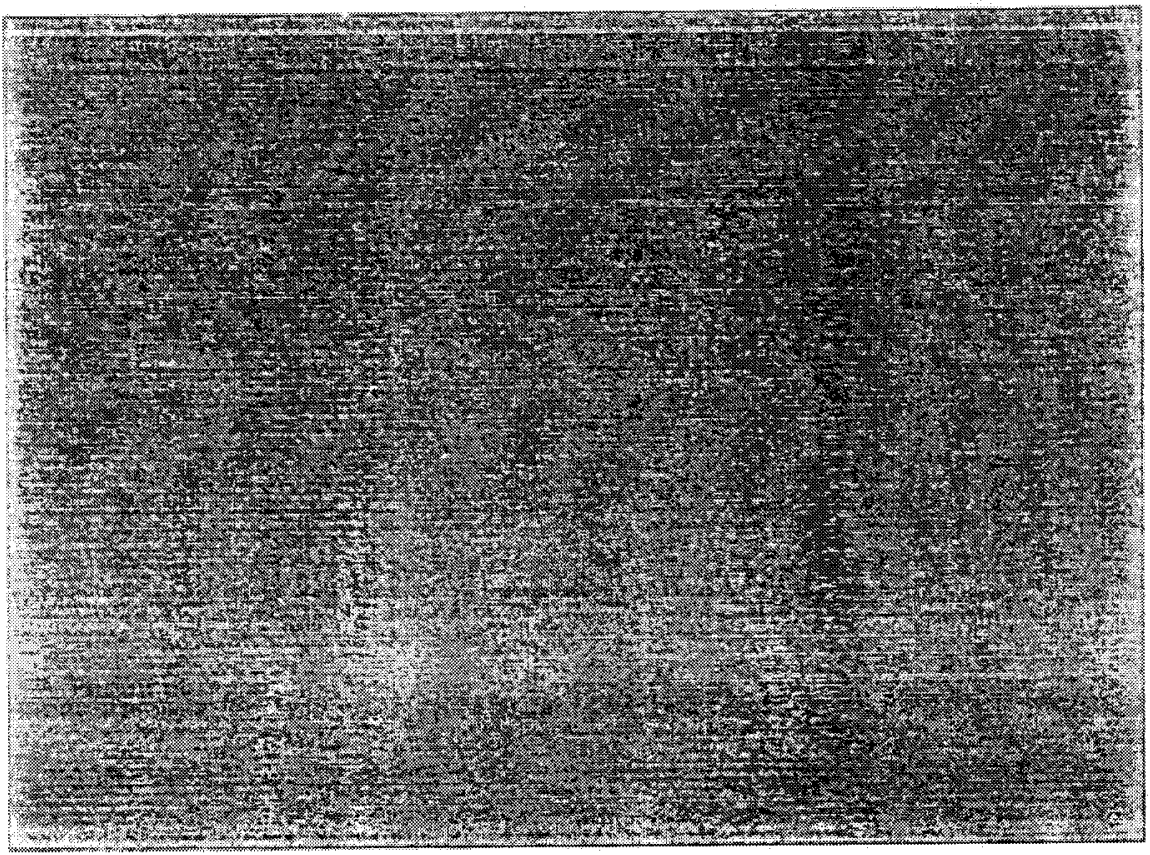

\section{gav}

\begin{tabular}{|c|c|c|c|}
\hline 4 & 85 & 菏櫒 & 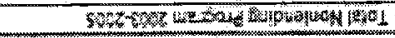 \\
\hline 3) & (at & 5 & $\pi \approx$ \\
\hline 裳 & 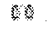 & 8 & ares \\
\hline 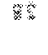 & W & 8 & 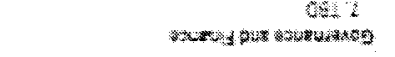 \\
\hline 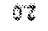 & 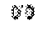 & 2 & (2) \\
\hline !! & F & $\theta$ & of? \\
\hline$\forall$ & 呫 & W: & 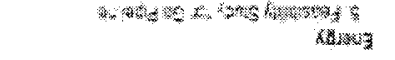 \\
\hline 策 & vo & ats & wets \\
\hline s? & V & 8 & mo brtw \\
\hline 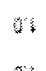 & os & 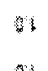 & 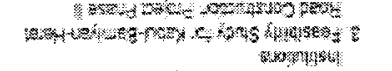 \\
\hline \% & 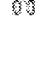 & m & 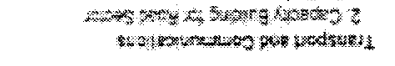 \\
\hline 娄: & w & Fi & 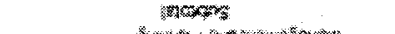 \\
\hline s & की & r. & 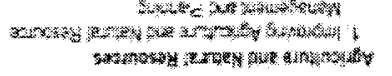 \\
\hline
\end{tabular}




\title{
AFGHANISTAN POSTCONFLICT RECONSTRUCTION
}

\author{
Presentation by
}

Frank F. Polman and Craig

Steffensen

June 2003

\section{Introduction}

When we speak of Postconflict

Reconstruction, it is more than new roads, bridges, and schools. It is about:

- Capacity building and

- Identifying and implementing the right set of policies and institutions 


\section{The National Budget}

- In the ADF, President Hamid Karzai appealed to the community to quadruple the aid package pledged in Tokyo in January 2002:

- Afghanistan would need \$15-20 billion over the next five years to rebuild vital social and economic infrastructure and to combat terrorism and drugs production

- There is a need for a new pledging conference in 2003 to firm-up longer-term commitments as most pledges made at the International Conference in Reconstruction Assistance in Tokyo in January 2002 would have been fully disbursed within the next year. 
$\ln$

Presentations 


\section{Construction Sector}

\section{Projects}

- Kabul Satellite City Construction (Ministry of Utban Development \& Housing)

\section{Kabul Satellite City Construction Project Outline}

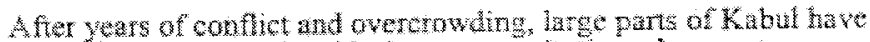
baten toully destroyed and lack proper santat ton. cleatn water

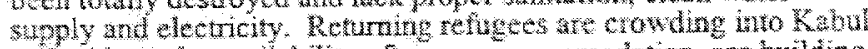

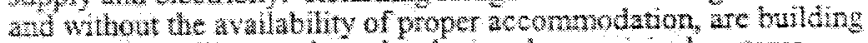

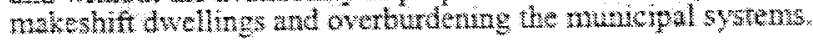

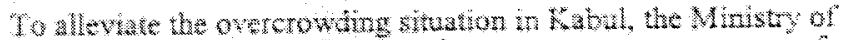

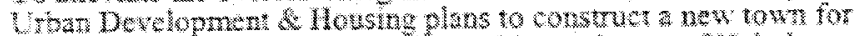
were thxn 700,000 nhabitants located is nontheast of Kabul.

The proposed project will include the provetion of a cean water supply system, electre powar supply, roads, phone lites, recteation patk, shools, makket center, shops, fre snd police stations.

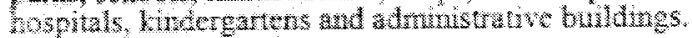




\section{Kabul Satellite City Construction}

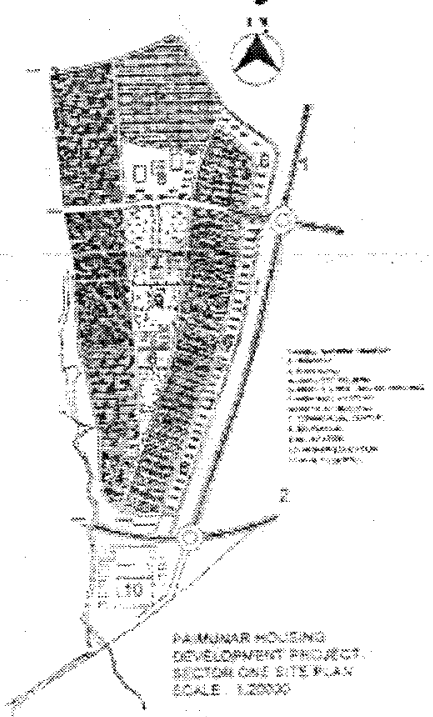

\section{Kabul Satellite City Construction}

\section{Project Site}

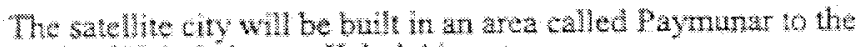
north of Kabul close to Kabul Amport.

\section{Proiect Status/Timeline}

The Mnistry of Unan Development and Housing has surted invertigatnd the a valablity of drinking water and locnthed

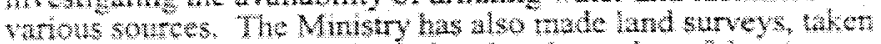

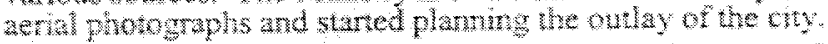
It forticipated that one district will be completed by the end of 2004 and thet the frot bateh of approximately 70,000 inhobiants will be able to move into the new development site. The new

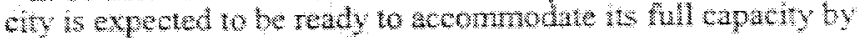
2013 


\section{Kabul Satellite City Construction Services \& Equipment (cont.)}

Services and Equipment for the city street construction:

- Enginecring servees in stree dosign and city road infrastucture:

- Cowstrutoun manazement anervision:

- Aspandi payement plants, asphalt pavers, and asphalt distributos:

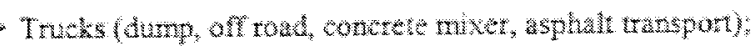

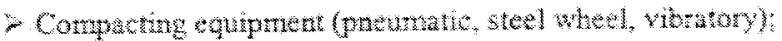

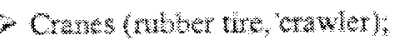

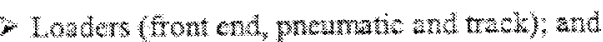

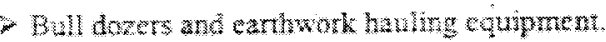

\section{Kabul Satellite City Construction}

\section{Project Financing}

Though the Afghan Government has started the initial phase of this project using its own funds, main project financing will have to be provided by multilateral funding institutions as well as private investors. 
Mr. Stein holds B.A. and J.D. degrees from the Unversity of Michigan. He is the anthor of wumetos articles on legal aspects of international trade and has served as Chaiman of the Unted Nations Working Pary on Intemational Contracts.

\section{Mr. Peer Stein \\ Senior Investment Officer, Banking Advisory Group IFC}

Peer Stem is a Senior Jnvesment Officer in the Banking Advisory Group. In this role, he leads FC's investment work in the microfinace and banking sector in Alghanistan. Further, he has global responsibilities for $\mathrm{HC}^{*}$ s investments in finuctal infrastructure, including credit bureaus and shared services companiss, and structurcs advisory services for banks and non-banks in prerging warkets and transition counthes. His most recent advisory and investmem work focused on Vietram, Chna, Egypt, Moroco, Rustia and Eastem Europe, Afghanistan, Pakistan, Central America, and Brazil. Peer Stain jomed IFC in 1906 to extablish the Coporation's Extended Reach Office in Mongolia. Subsequently, he moved to the Financial Markets Subm Saharan Africa Department as an Investment Officer, focusing on frnancing urban and nra morofinance institutions, risk management facilties and oredit lines for banks, and capital markets development. Pror to joining IFC, Peer Stein worked in Germany as a management consultant in enterprise restructuring, and as a partner in a strategic market rescarch firm covering Eastem Europe. He holds a Masters degree in Economics and Business Admistrationt fom Witen/Herdecke University, Gemany's frst private university.

\section{Mr. Robert Sweet \\ Federal Aviation Administration}

\section{Ambassador William Taylor Jr. Reconstruction Coordinator United States Embassy, Kabul, Afghanistan}

Ambassador Bill Taylor is currently sering as the Special Representative for Donor Assistance to Afghanstan. Working closely with the Afghan government and international donors out of the US embassy in Kabul. Ambassador Taylor is fachitating the flow of existing intemational assistance to Afghanistan and encouraging more.

Prior to this job, he coordinated the US government's assistance to the former Soviet Union and Fastem Europe. He oversw the bilateral economic, securty, democrasy and humaniarian assistance to these 27 states. 
Dr. Shahghasy was bom in 1949 in the Logar Province of Afghanistan. In 1964 he began studymg cariography in Kabu, Aghanistan. In 1969, he curolled in the reserve's training force of the Afgha Amy, After the army training, he enrolled in a polytechnic university. Upon graduation he began working as a civi engineer for the Afghan Ministry of Public Works. In 1985. Deputy Minister Shahghasy was appointed Deputy Director General of General Directorate of Roads and Aiports of the Ministry of Public Works.

In 1988, the Deputy Minister went to the former Soviet Union to get his doctorate in road bulding. Upon his retum to Afghanistan in 199, he held many posts at the Ministry of Public Works, leading to his current position of Deputy Minister.

\section{Ms. Virginia Sheffield \\ Principal \\ Sheffield Associates}

Virgina $K$. Shefield is leading negotiations for Telephone Systems Intemational and Afghan Wireless to obtain a GSM servee heense in Afghanstan. She is President of Sheffeld Advisors. a consulting firm specializing in regulatory and public aftairs and development for conmunications companies. Ms. Sheffeld has been working with TSI since March of 2002. She recently retumed from her fourth trip to Afghanistan, where she has been working closely with the Ministry of Communications on heensing, regulatory and comporate govemance issues.

Ms. Sheffield has more than 20 years of private and public sector experience as an economist. administrator and analyst in the teleconmunications industry. Pror to foming Sheffeld Advisors, she was Vice President, Regulatory for Genuity a tier-one Internet backbone provider. There she oversa domestic and intemational regulatory maters and helped the company enter regulated and uregulated services narkets. She also was a member of the team that separated Genuity from GTE through an LPO in Jume 2000. Prior to Genuity, Ms. Shefheld worked for the then largest U.S. independent telecommunications carrier, GTE, as Assistant Vice President Regulatory Policy for both GTE and GTE Mnternetwotking.

Ms. Shefield has also served as Director of Telcommunications Policy at we lowa Commerc Commission, where she lead the state's deregulation of a number of services. She began her carec as Principal Fincal Analyst for the lowa General Assembly. She has been Chairperson of the Michigan State Institute for Public Uthies Executive Committee and Industry Advisory Boards.

\section{Ms. Jennifer Snyder \\ Manager, Caspian Business Development U.S. Trade \& Development Agency}


Wintam Polen is the program manager for Europe and Eurasia for the United States Energy Assocition. The Unted States Energy Association is the US commitee of the World Energy Council and a 150 member non-profit association, whose membership includes oil and gas companies, electric wilities, energy equipment manufacturers, consulting firms, and fedenal and state government agencies. As USEA* s program manage for Europe and Eurasia. Mr. Polen dircets the association": cooperative programs with the US Agency for Intertational Developmen, US Department of Energy and US Trade and Development Agency in the Balkars region. Contral and Eastem Europe and the netions of the fomer Sovict Unon. Most recenty hese programs have focused on encouraging regulatory reform, whity commercialization and he development of compettive markels to estabhish favorable conditions for private investryent in the energy sector.

\section{Mr. Frank Polman Senior Advisor Asian Development Bank}

Mr. Frank J. Polman is Senior Advisor, South Asia Department of the Asian Development Bank (ADB). He assumed the position on 12 August 2002.

Mr. Polman is responsible for ADB's strategies and policies, and subregional cooperation programs in Soutn Asia. He serves in a concurrent capacity as the Special Representative for Aghanistan, in charge of $\mathrm{ADB}$ 's program in that country.

Previously, he served as Country Director of the India Resident Mission, ADB since January 1999.

Mr. Polman has bect with ADD for 20 years, serving in various capacities in the felds of econonic ard sector policies, project appraisal, country program, and portfolio management.

Pror to joining ADB, he worked for the Dutch Development Aid Department of the Ministry of Foreign Arars in Sri Lanka. West. Africa, and the Carbbean. He taught Agriculural Economics at the University of Wageningen In The Netherlands. He has writen several publications in the arcas of employment, income distrbution, agricultural economics, and nural development.

Mr. Pohman holds a Doctorate in Development Economics from the University of Wageningen and a Master" in Science in Agriculural Economics from the same University. He attended courses at the Harvard Institute for International Development and at ADB in the areas of mactocconomic adjustment and management. 
Prior to joining the Bush Cheney Campaign, Mr. Murphy was Deputy Counsel of the Republican National Commitee. During that tme, he served as Deputy General Counsel to the Rules Committee of the 2000 Republican National Convention; as a Counsel to the Platom Committe of the 1996 Republican National Convention; and as Counsel to the RNC Rules Commite. Mr. Muphy also directed the Republican Parys 2000 delegate selection and allocation process, and served as its Counsel to the Advsory Commisson on the Presidential Nominuating rocess.

Fomerly. Mr. Murphy was Legislative Assistant to Congressnan Charles Taylor (R-NC), handling a range of issues including foreign affars and intemational trafe. He also served as Aseciate Staff for the U.S. House Commerce, Justice, State and Judiciary Subcommitee on Appropriations.

Mr. Murphy has a B.A. from Indiana University, and a J.D. from Indiana University School of Lux.

\section{Dr. M. Ishaq Nadiri \\ Economic Advisor to the President of Afghanistan}

Professor Nadin emigrated from Afghanistan to the United States at the age of 19 and receved his B.S. from the Unversity of Nebraska, and his M.A and Ph.D. from the University of Calforma, Berkeley. He has tught at UC Bekeley, Northwestern Universty, Unversity of Chicago and Columbia University. He joined New York University in 1970 and has been the chatiperson of the Economics Department and the founder and first director of the C.V. Start Conter for Applied Economics. He was named a Jay Gould Professor of Economics in 1975 and was a Distingulshed visiting professor at the Amencan University in Caro in 1993. He is an axthor of more than 100 published papers in leading professional joumals and several books on productivity, technological change and economic growth.

Professor Nadit has served as a consultant to a number of comporations, governments and international organzations including United Nations Conference on Trade and Development, United Nations Association, the Center for Srategie and Intemational Studies and as the leader and a nember of the International Review Committee of the Ministry of Plamirg for the Kingdon of Saudi Arabia. He is a nember of Comeil on Foreign Relations, American Economics Association, C.V. Star Center for Applicd Lconomios. Contror for Japan-U.S. Busmes \& Economic Studies, Committee for Economic Development, Editorial Boatd Member of the Amals of Economics \& Socid Measurment. He is histed in Who's Who in Economics,

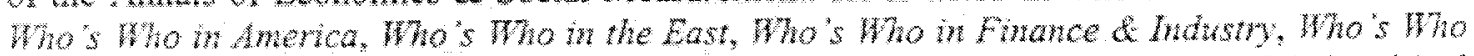
in Scrence \& Engueerng. Who's Who in Amencan Edwcation, the Dictionary of Distinguished Leaderwip, Men of Achevement, 5,000 Personalities of the World, and Personalitics of the Americas.

In addition Professor Nadiri has been actively involved with reconstruction effors in Afghnistan. He was a signatory of the Bonn metings on Afganistan where the now interm 
Ms. Monique Koning

Manager, Special Projects Group

MIGA

Ms. Koning, a Dutch natonal, joined MGA in Septenber 1997, as underwhter for Furope and Contral Asia. She joned a business process revew team in MOA's Guarantes Deparment dwring 1998, and then became Sr. Underwiter and Depuly Manager for the County Development Group (CDG). Her main foes in CDG was on developing on new courtry risk system for political risk insurance. In January 2001, she transferred to the Operational Strategy Unit, where she heads up a small tean called Special Projects. The Special Projects Unit is responsble for product developwent and imovation in political risk insurance, the development of loint products with the World Bank and IFC, and for underwiting policies and openational strmegies in the Guarantec Deparment. Ms. Koning has been a staff member of the World Bank Group since 1993. Prior to joining MIGA, she worked as Country Office for Bosmia and Herzegowina in the World Bank. In the period of 1993-1995, she was (Strion) Advisor to the Executve Director in the World Bank representing the Netherlands, Amenta, Bosnua and Herzegovina, Bulgaria, Croatia. Cyprus, Former Yugoslav Republic of Macedonia, Georgia, Israel, Moldova, Romania, and Ukrame.

Ms. Koning has had extensive experience in the area of polical rist insurance, and strategy formulation and implementation as it relates to the role of the private sector in development. $\mathrm{Ms}$. Koning received her MSc in Econonies from the University of Amsterdam.

\section{Ms. Merriam Mashatt \\ Director, Trade Policy Division \\ U.S. Department of Commerce}

\section{Mr. Alastair McKechnie \\ Country Manager for Afghanistan World Bank}

Alastair McKechnie is currenly Country Director for Afgharistan and Operations Director for the South Asia Region in the Ford Bank where he assists the Vice President for the region and oversees the Bank's operations in all sectors in the eight curenty active borrowers in South Asia. In Jamuary 2002, be was given an additional appointment as Country Director for Afghanstan where he drects Batk assistance to that country. Pror to taking up the Operations Director appoinment in July, 2001 , he was the energy sector director for the South Asia Region where he was responsible for the Bank's energy operations in Bangladesh, India, Nepal, Pakistan and Sr Latuka He was also a member of the Bank's energy sector board which formulated the Bank s energy sector policies and guded evergy sector operational and knowledge activities. 


\title{
Mr. Khaliq Fazal
}

Chairman

\section{Evaluation Commission of State Owned Enterprises}

\author{
Mr. Craig Fedchock \\ Chief of Staff, International Services, APHIS \\ U.S. Department of Agriculture
}

\section{Ambassador Robert Finn \\ U.S. Ambassador to Afghanistan}

Robert Patrick lohn Finn was swom in March 22, 2002 as the new U.S. Ambassador to Afghanistan at a ceremony in the U.S. Embassy-Kabul. In remarks to the Embassy staft, he sad: "My being here as Ambassador marks the commitment of the United States to a new relationshp with Afghanistan, and a rew relationship with the long-suffering people of this country. It comes. of course, in a time of war, when the nations of the wond have united to stop the forces of terrotism that took this naton hostage and theaten the world. The struggle against these forces continues, and will contrue to demand sacrifices and create victims."

Rober Patrick John Finn, a career member of the Senior Foreign Service, is from New York. He is currently diplomat-in-residence and Ertegun Professor of Turkic Studies at Princeton Universty, From 1998 until July 2001 , he served the United States Ambassador to Tajikistan.

Prior to that, he served as Deputy Chef of Mission at the American Embassies in Croatia (19951998 ) and Azerbainan (1992-1995). He opened the Embassy al Baku in 1992. In 1991, he servel as Director of he American Embassy Office in Diyarbakir, Turkey, durng the mitial montss of Operation Prove Comfort and xas Deputy Coordinator of the Kuwat Task Force dung the Gulf War.

Le also seved as Deputy Principa Officer of the American Consulate General in Lahore, Pakstan, fom 1984 1986. He has had several different towrs in Ankara, Izmir and Istanbul, Turkey.

Mr. Fint has a B.A. in Anerican Literature and European History with honors from S1. John's University, and an M.A. knd Ph.D. in Near Eastem Studes from Princeton University. He also has an M.A. in Near Eastem Studies fron New Yok University. He sarved as a Peace Corps Volunter in Tukey from 1967-1969, and was a Fubright Scholar at the Turkiyal Instimte of Istanbu Univerily fom 1976-1972. His publications encompass a book. The Earlv Turkith. Nove. $1872-1900$, and poems, articles and translations in English and Turkish. 


\section{Mr. Donald Boy}

\section{Desk Officer for Afghanistan \\ U.S. Department of State}

Mr. Boy joined the Office of Afghanistan Reconstruction shorty ater its fomation in the Summer of 2002. Immediately prior he was an Afgan Desk oftecr in the Offec of Pakitat. Afhanistan and Bangladesh. Since entering the State Deparment in 1000, Mr. Boy has served overseas in Mexico, Costa Rica and Togo. He has also served as the Afehmistarkepal analyst in the Burew of Intellyence and Research and as Desk offeer (Cote Wvoire Togo Benin) in the Offee of West Africar Afrirs in the State Deparment in Wasington. Mr. Boy has a Masters degree in Anthropology from the University of Massachusets and a Bachelors degree in Wistory from swathmone college.

\section{Mr. Jay Brandes}

\section{Director, Afghanistan and Iraq Reconstruction Task Forces International Trade Administration U.S. Department of Commerce}

\section{March 2003 - Present}

Currenty serving as the Deparment of Commerces's Drector of the Intemational Trade Administration's Mraq Reconstuction Tas: Force.

\section{December 2002 - Presen}

Currently sarving as the Department of Commerce's Dimector of the Intemational Trude Aministetion" 's Ahanistan Reconstructon Task Force.

\section{Cobruary 2000 - June 2002}

\section{Acring Director of the U.S. Department of Commerce's Advocacy Center.}

The Advocacy Center is the main point of contact for US. firms bidaing on foreign govemment procurements seking U.S. Goverment assistance. The Advocacy Center, in cooperation with the wrious TPCC agencies, coordinates aggressive, Largeted strategies to combat the strong lobbying eforts of our foreign compettors. The Center, whin a staff of 14 , leads the charge in finc figh to level the playing feld and promole open competition in the intematonal bidding wenc from a nultimilion dollat infrastructure project to a strategic contract for a small busines:

\section{November 1993 - Fobruary 2000}

Depuly Dinector of the U.S. Department of Commerce's Advocacy Center.

\section{March 1993 - November 1993}

Assigned to the Major Projects Division in MA. Responsibitutes included supporting U, cxporters pursuing petrochemical, chemicals, all 6 gas, pipelines, mining, shiphulüng. and minerals and rretals major projects in foreign coumeres. 


\section{Mr. Ramin Asgard \\ Economic/Commercial Officer \\ U.S. Embassy, Afghanistan}

\section{Honorable Thelma Askey \\ Director \\ United States Trade \& Development Agency}

Thelma J. Askey was sworn in as Director of the Trade and Development Agency on June 4, 2001. A native of Tennessee, Ms. Askey has more than twenty years experience in the trade field and has been a key player in the development of U.S. trade policy beginning with implementation of the Tokyo Round of Multilateral Trade Negotiation in the early eighties.

Most recently, Ms. Askey served as one of six Commissioners on the International Trade Commission. Appointed by President Clinton, Commissioner Askey was swom in on August 7, 1998 to complete an unexpired term and served until January 16,2001. The ITC plays a broad rote in international trade matters. Particularly, commissioners collectively determine whether domestic industries are being injured by reason of Imports that are sold at less than fair value (dumping) in the U.S. or by imported articles that benefit from govermment subsidies. The TTC also reviews injury caused by rapidly increasing imports of fairly traded goods and may take action to counteract certain unfair trade practices, such as patent, trademark or copyright infringement. The agency also conducts studies on trade and tariff issues for the purpose of supporting trade negotiations or providing technical advice to the U.S. govemment on a variety of trade matters.

Prior to her appointment as Commissioner, Ms. Askey served as the Staff Director of the Trade Subcommitte of the Committee on Ways and Means, U.S. House of Representatives. In that role, she was the principal trade advisor to the chaiman of the committee and other Members and was responsible for the development and processing of the stbcommittee's trade agenda, including oversight of multilateral and bilateral negotiations, fast-track extensions, China's normal trade relations status and WTO membership, trade relations with non-market economies, and oversight of key bilateral and multilateral trade agreements, particularly NAFTA and the WTo.

Ms. Askey is originaly from Millington, Tennessee in the western part of the state. She holds a Bachelor of Ants degree in history from Tennessee Technological University and has completed graduate work in law, history and international economics at the University of Tennessev, George Washington University, and American University. She has one daughter, Joelle. 


\title{
SPEAKERS, MODERATORS \& OFFICIALS
}

\author{
Ms. Adina Renee Adler \\ Afghanistan Task Force \\ U.S. Department of Commerce
}

Ading is the US Deparmen of Commerce's internatona trace speciahs for Afghamstan, Paktan, and Bangladesh. While pronoting U.S. exports to South Asia, she work wo fachitate fair practics in intemational trade by monitoring market acess and complianoe issues in the

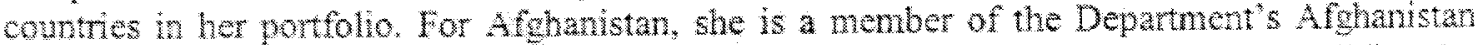
Reconstruction Was Force and is supporting the Adninistration"s commitrent wo rebulding the warmm country by contrbuthg to tride policy issues and working wh the U.S. private sector to gain a footold in this rew and exparding maket.

Adn has ben win the Dopartment snce May 2000 and hes wo worked to promote exports by supporting the Foreign Commercial Service staff in U.S. posts overseas and responding 10 U.S. company inguincs on exporting to the Far East

Adina holds a Bachelor's deztee in International Affirs from The George Washington University in Washington, DC; and a Master's degree in International Economos and Intemational Relations from the Jolms Hopkins University School of Advanced Intemational Sudies (SAS) in Washngton, DC.

\section{Dr. Anwar-ul-Haq Ahadi \\ Governor \\ Central Bank of Afghanistan}

\author{
Mr. Raz Mohammed Alami \\ Deputy Minister \\ Ministry of Civil Aviation \& Tourism, Afghanistan
}



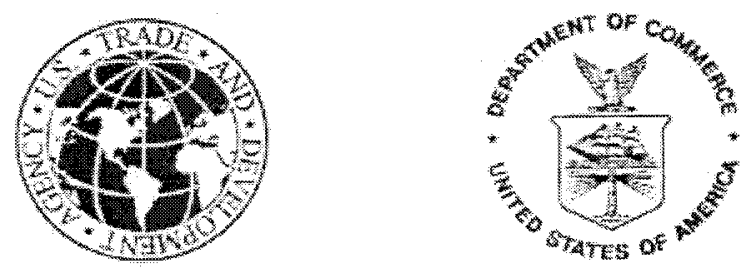

DEDICATION

This conference is dedicated to the menory of Joma M. Mohamadi. Born in Afghanstan and educated in both Afghamistan and the United States. Jowa Mohamadi headed Afghanstan's Minstry of Water and Power in the 1970 's. Forced to flee the commy after the Soviet invasion, Minister Mohamadi then emigrated to the United States and began a new career at the World Bank, where he sened with distinction until his retirement in 1999.

With the fall of the Taliban regime and the creation of the new govenment led by President Hamid Karat, Minster Mohamadi retumed to Kabul in the summer of 2002. at greal personal sacrifice, to serve his motherland as Minister of Mines and Industries in the Transtional Islamic State of Afghamistan. He was lost in an arplane crash in Pakistan in February 2003. 
Conference Program Agenda

Speakers, Moderators \& Officials

\section{Presentations}

Corporate Sponsors and Supporting Organization Information

General Conference Information \& Evaluation Forms 


\section{Conference Program Agenda}




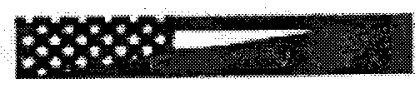

\section{Afghanistan Reconstruction Conference}

Co-organiced by the US. Trade and Development Agency and the U.S. Department of Commerce June $8 * 10,2003 \cdot$ Chicago, IL.

3une 5.2003 1. 4.2

\begin{tabular}{|c|c|}
\hline Sunday June 8 & \\
\hline $300 \mathrm{PM}-700 \mathrm{PM}$ & $\begin{array}{c}\text { Registrafion } \\
\text { foyer, } 2^{\text {ti flom }}\end{array}$ \\
\hline $3.30 \mathrm{PM}+4.30 \mathrm{MM}$ & 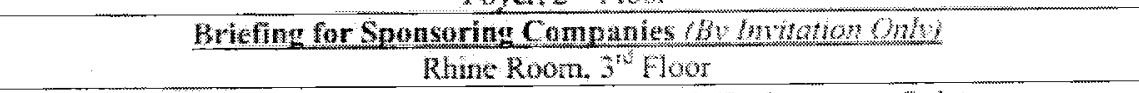 \\
\hline $500 \mathrm{PM}-5.45 \mathrm{MH}$ & 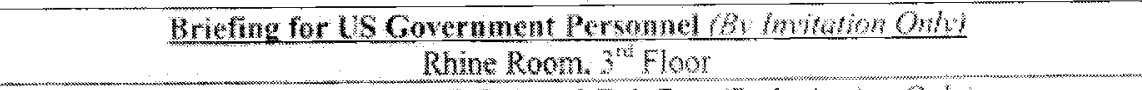 \\
\hline $600 \mathrm{PM}-7.00 \mathrm{PM}$ & 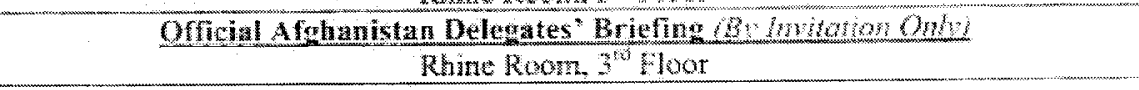 \\
\hline $700 \mathrm{PM}-8,30 \mathrm{PM}$ & 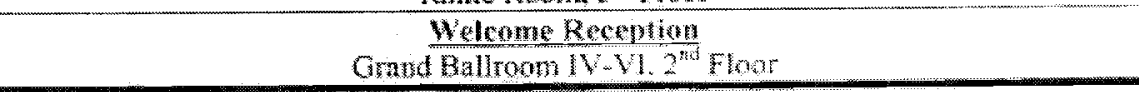 \\
\hline Monday June 9 & \\
\hline $7.30 \mathrm{AM}-8.4 \mathrm{BM}$ & 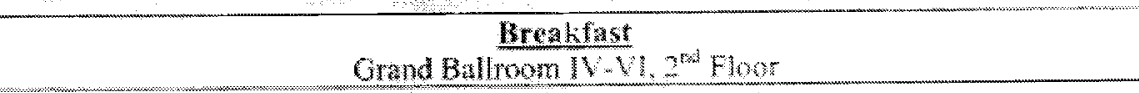 \\
\hline $845 \mathrm{AM}-9.45 \mathrm{AM}$ & 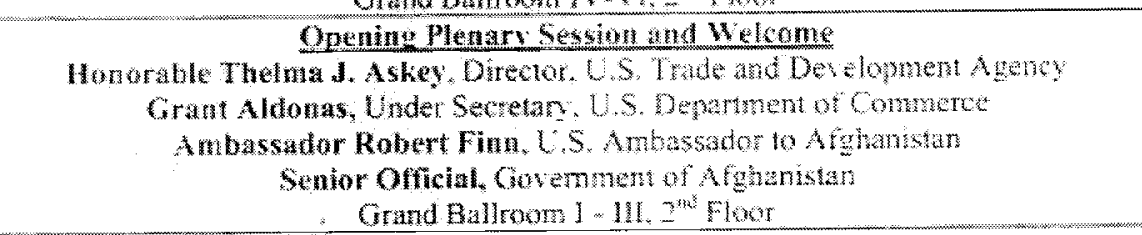 \\
\hline $9 \cdot 65 \mathrm{AM} \cdot 10.45 \mathrm{AM}$ & 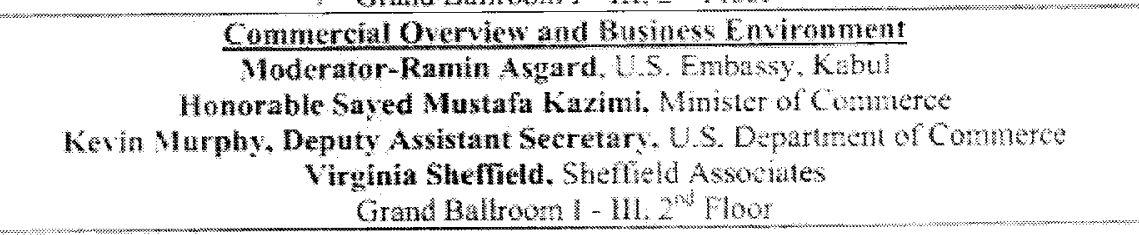 \\
\hline $10,5 \mathrm{AM}=11.60 \mathrm{AM}$ & $\begin{array}{c}\frac{\text { NetworkingBreak }}{\text { Foyer }- \text { Hoor }} \\
\end{array}$ \\
\hline MISAM-11.45A & 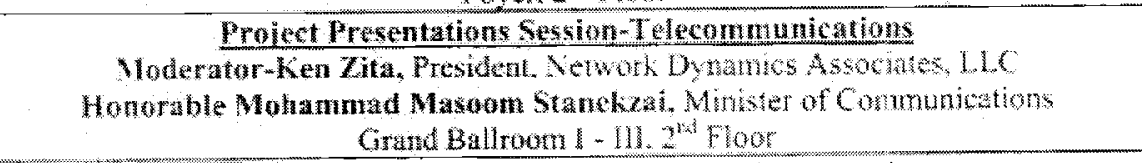 \\
\hline $11.45 \mathrm{AM}=12.30 \mathrm{M}$ & 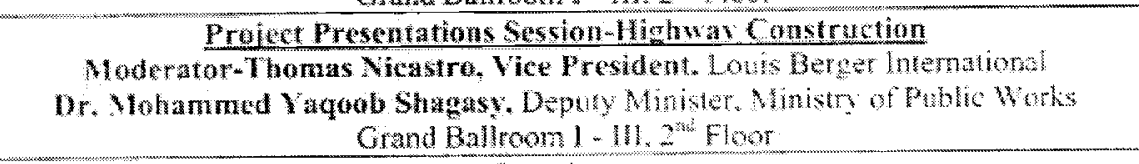 \\
\hline $1245 \mathrm{P}=3.15 \mathrm{PA}$ & 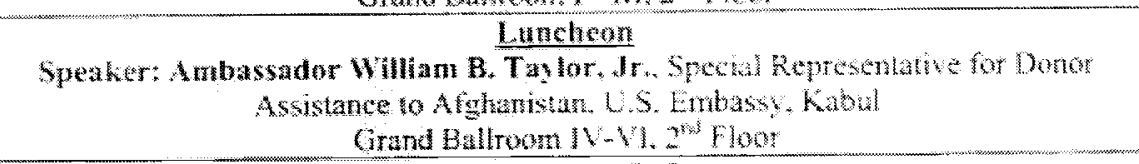 \\
\hline $3.30 \mathrm{PM}-3.30 \mathrm{PM}$ & 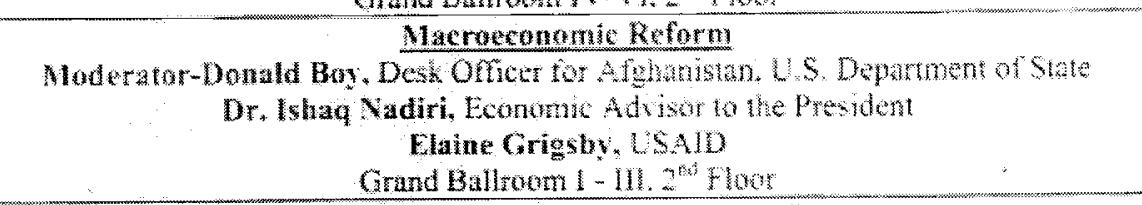 \\
\hline $300 \mathrm{PM}-3,30 \mathrm{PU}$ & 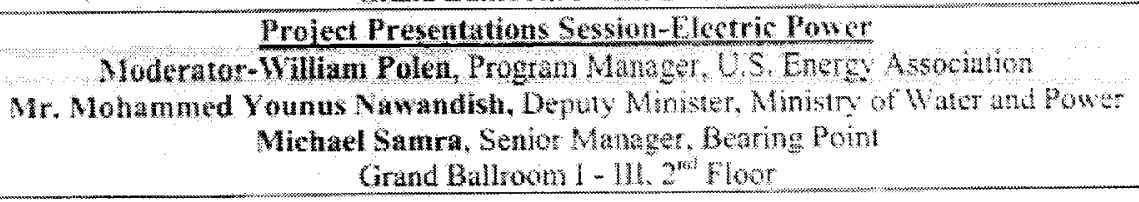 \\
\hline
\end{tabular}




\begin{tabular}{|c|c|}
\hline $3.30 \mathrm{PM}-6.00 \mathrm{PM}$ & 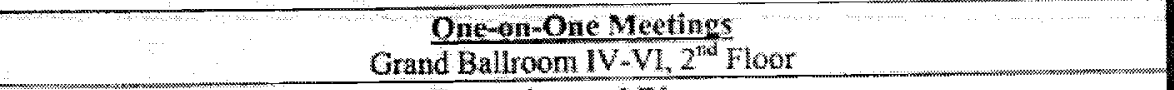 \\
\hline $7.00 \mathrm{YM}-9.30 \mathrm{MM}$ & 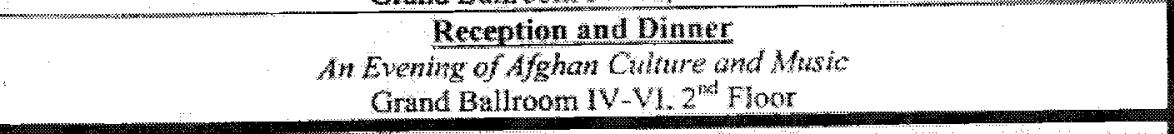 \\
\hline Tuesday June 10 & \\
\hline $730 \mathrm{AM}-2 \mathrm{~B} B \mathrm{AM}$ & 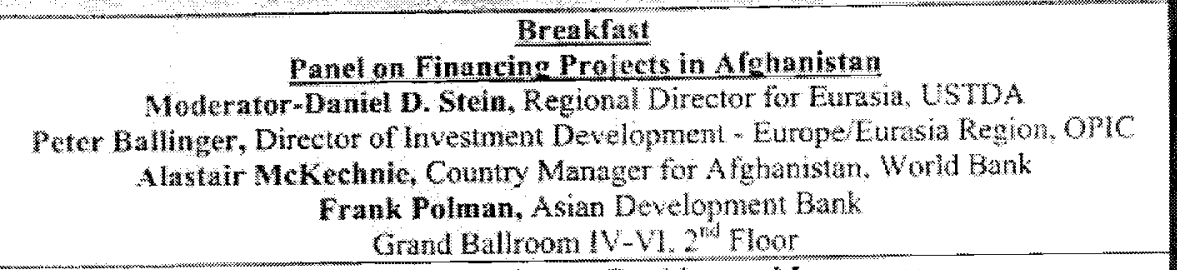 \\
\hline $900 \mathrm{AM}-1000 \mathrm{AM}$ & 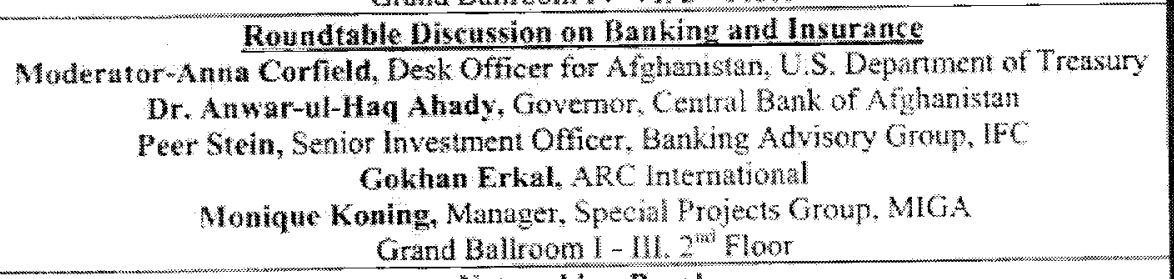 \\
\hline $1000 \mathrm{AM}-10: 15 \mathrm{BM}$ & $\frac{\text { Notworkind Breal }}{\text { Foyer, } 2^{\text {st }} \text { Foor }}$ \\
\hline $10: 15 \mathrm{AM}-10.45 \mathrm{AM}$ & 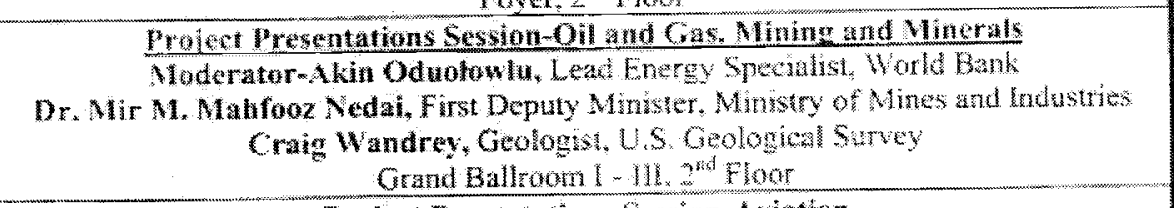 \\
\hline $1100 \mathrm{AM}-11: 30 \mathrm{AM}$ & 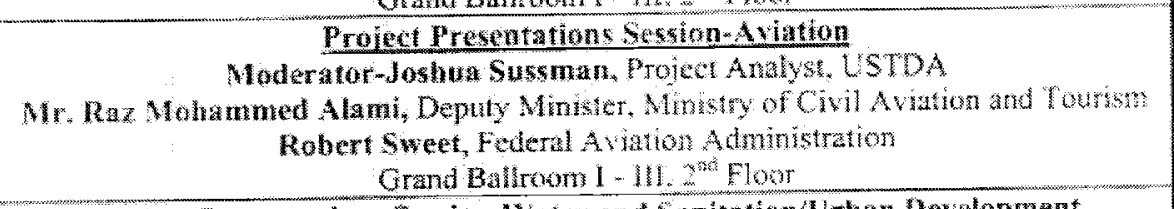 \\
\hline $1130 \mathrm{AM} \times 12.00 \mathrm{AM}$ & 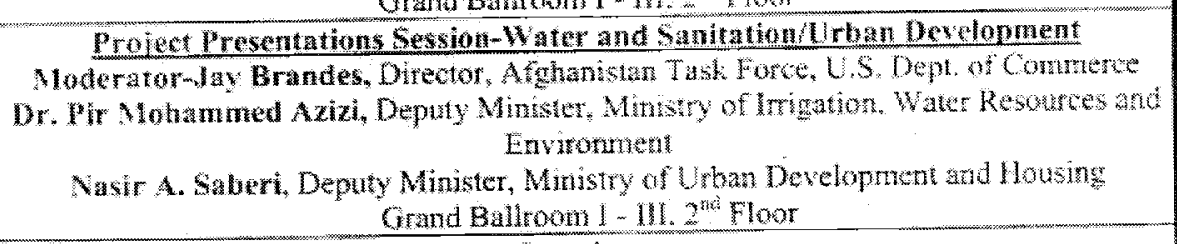 \\
\hline $1215 \mathrm{MM} \times 1.45 \mathrm{MM}$ & $\begin{array}{l}\text { Lunchean } \\
\text { Grand Balloom Y Y Y. 2 } 2^{\text {st }} \text { Floor }\end{array}$ \\
\hline $2: 00 \mathrm{MM} \cdot 3.45 \mathrm{mM}$ & 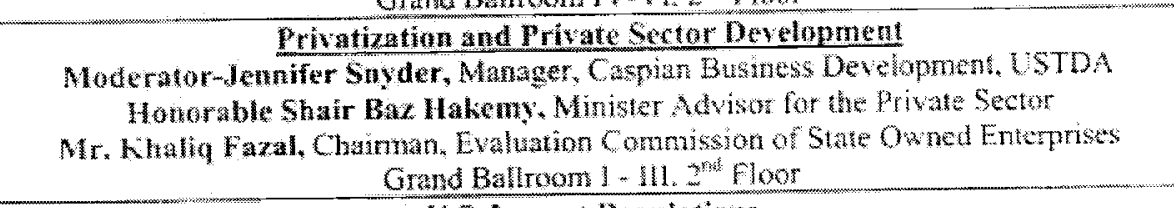 \\
\hline $2.55 \mathrm{PM}-3.30 \mathrm{pM}$ & 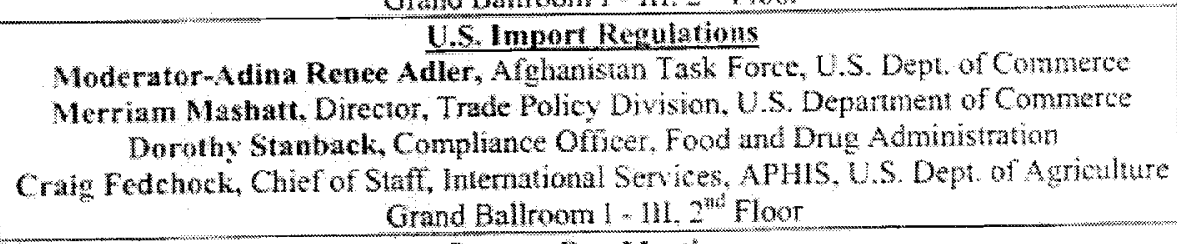 \\
\hline $3.30 \mathrm{PM}-6.00 \mathrm{PM}$ & $\begin{array}{l}\text { Oneonone Meetirgs } \\
\text { Grand Ballroom W-V.2.2 Fioor }\end{array}$ \\
\hline
\end{tabular}

* Joviged 


\section{SILVER SPONSORS}

\section{Case New Holland}

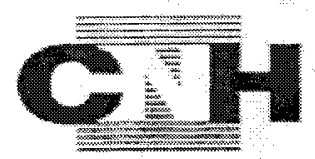

Case New Holland Inc.

\section{Overview and Background}

Case New Holland Ine. (CNH) is the number one manufacturer of agricultural tractors and combines the world, the third largest maker of construction equipment, and has one of the industry's largest equipment fnance operations. Revenues in 2002 totaled $\$ 10$ bllion. Based in the United States, CNH's network of dealers and distributors operates in over 160 countries. CNH agricultural products are sold under the Case 14 , New Holland and Steyr brands. CNH construetion cquipment is sold under the Case, FiatAllis, Fiat-Kobelco, Kobelco, New Holland, and O\&K brands.

In October 2002, CNH led a business development mission to Kabul to meet with the new Afghan Government, In January 2003, CNH opened a corpotate office and distributorship in Kabul. CNH intends to establish service centers in the near future. To date, CNH is the only western manufacturer to open an office in Afghanistan.

\section{Agricultural Equipment}

As the parent of the Case IH and New Holland worldwide agricultural brands and Steyr, a regional European brand, $\mathrm{CNH}$ manufactures the broad range of equipment used on every farm and livestock operation around the world. Through its complementary brands, $\mathrm{CNH}$ offers equipment solutions that meet the regional requirements for large-scale growers, wility producers, otchard and livestock operations. The company's mission is to provide customers with the product, service and support solutions that increase their productivity and add value in the field.

Through its reputable brands, CNH manufactures high and low horsepower tractors for use in every application from cash grain production to lawn and garden maintenance, rotary and conventional combines, hay tools, mplements and self-propelled sprayers. With is range of harvesting equipment, $\mathrm{CNH}$ offers the product of choice for a wide variety of specific applications, including cash grain, hay and forage, cotton, sugar cane and grape producers. CNH

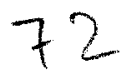




\section{US-Tronics}

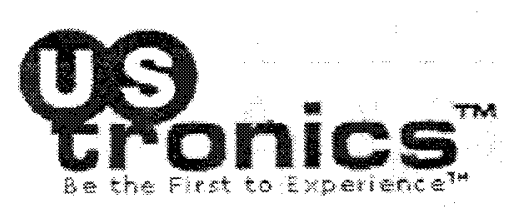

UStronics is an independent distributor of wireless communications products and services. Founded on March 8, 2000 and headquartered in New York, U.S.A., UStronics provides services to global wireless carners, distributors and dealers in more than 11 countries around the world. We provide a complete and diversified range of brand name products with the best service and value for the world maket by attracting and retaining the most professional and qualified exployees while generating consistent and optimal retum on investment.

UStronics in partnership with Afghan Com (www.afghancom.com) recently lawnched the hist largest hi-tech equipped Internet cafe in Kabul. The services are included but not limited to providing of high-sped Internet connection, distribution ship of wireless products and services. computer and Internet training courses, video conferencing etc.

Because of UStronics' excellent relationships with all major wireless manufacturers we are able to offer a broader selection of wireless products and services.

Our Values:

\section{Strengths:}

- Exced customer expactations .......

- Inspire the highest level of honesty and integrity

- Committed to the success of our business partners

- Value teamwork and loyalry

- Knowledge in the North American, Asian \& European markets.
- Strategic logistical locations.

- Broad selection of products ard servi

- Ofering the right products and solut

- Experience in the industry and well fo

- Company name recognition

New York Office $-5808^{\text {th }}$ Avenue, $10^{\text {th }}$ Floor, New York, NY 10018

Tel: (212) 840-4333 Fax: (212) 840-6299

Web Site: www ustronics.com 


\section{Swiss Skies}

\section{SWISS SKIES}

Swiss Skies is a Swiss company that, in parmership with World Arways, is pionecring direct scheduled air service from Washigton, DC to Kabul via Geneva. The wice weekly flghts on MD-11 aircraft, operated by World Arways, will support the reconstruction efforts in Afghanistan by providing secure and effeicnt travel altemative to Kabul for government officils and private sector organzations. Thighis will begin in mid-July.

Currently, ravel altenative from the U.S. 10 Kabul represen an exhausting ordeal requing 35 or more hours, in some cases reguring two plane changes, flying on air carriers not centifed by the $F A$, and or cnowng layovers in less than-safe citues. Unon arrival in Kabul, traveler have to recuperate before they can begin to work that need is just as pronounced when travelers retum 10 the Us.

In contrast the Swiss Skes option has been designed from the bothom up to maximize traveler security, productivity and convenience. Passengers from the U.S. and furope will benefit from an integrated security system that begins with a "Known Traveler" program. World Ainways, the arcraf operator, has provided safe and rehable air services to many challenging destritions dring wore than 55 years of service. World's safety procedures and margins ar exced other carriers", and are specifically adapted for dificul travel missions.

Passengers will enjoy an enhanced business class product. Every product feature - from the menu to $\mathrm{AC}$ ports for laptops to onhoard customer service agents (trained to assis: with logistics, planing and questions about Kabul) - is intended to cusure that travelets are productive and arrive $\mathrm{m}$ kbul rested and ready 10 work. Our eary moming fights from Washinglon. DC will take about 18 hours, including 2 stop in Geneva, with no change of plane, thereby ensuring that your luggage arrives when you do.

The Busmess Travel Coallion, a leading U.S. advocacy organzation for busmess travelers and organzations tha purchase largs volumes of commercial passenger services is endorsing the Swiss Skies product and providing sales and marketing suppor in helping bring this innovation to matkot.

To leam more about Swiss Skies, please visil our Web site at wWw-sh 1 sskes,com.

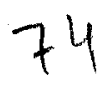




\section{IATECH}

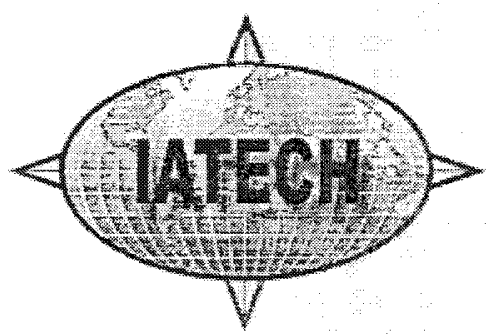

Inter American Technologies Co. www lafechnologies.com is a guality group of mamufacturty companies that buld hevvy-duty construction and agriculural equpnent. Companies provide vorkwide in-ountry traming service programs and equpment is desugned for trged, remote condwons and haxe exellen field reputatons. Brands considered especialy suted to reconstruction projects in Afgharistan:

1. VANGUARD heavy-duy $4 \times 4$ tractors come in 146 to 500 thorepower sizes. Applications incude heavy haulage, wility and asso eartmoving seraper applications. Company manufactures a line of portable pemanen water supply and purifoation equiptrent and is a recognized leade: in the world sugat industry haresting and assorted transportation equipment manufactur. Inter-American Transport Equpment Company, Ltd. was csablished in 1961 and is baged in Miani, Forida, USA.

2. REXVODS pull-type scrapers are considered the standard of the earthmoving industry These heavyduty earhroving units are used wh agncumural tractors and range in sizes from 5 to 20 cubio yards and are used in single, tandem or in trains of three configurations. Cost per cubic-yart-of-cath-moved compares favorably aganst other ypes of carthmoving products.

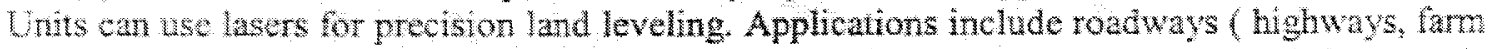
rads, land forming), mining materias ( clay 8 kaolin, diatomacous earth, sand \& gravel) public works (ampons, beach restoration, sanitary landflls), commercial ( houging, lakes,

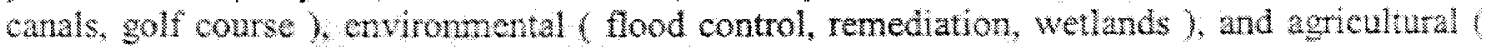
row crops, the fields, fish ponds, sugarcane, shrimp ponds, waste lagoons /. Reywolds International, L.... bomded in 1953 , based in McAllen, Texas, USA.

3. ROME plows are heavy-duty plows for aerating sols in road buiding applications and are ranown fow land cleang and havy eathwork applications. Egwpment also includes large towed constuchow scrapers, motor grader sppers, bedding harows, toolbar buldozer arangements. KG land cleatig blades, subschcr, 3 -point hiches, ditchers, muth-application rakes, and blades. The Company, Rome Plow Company, L.P. Was establiched in 1932 and is basen in Cedartown. 


\section{Caterpillar}

\section{CATERPILLAR}

For more than 75 years, Caterpillar Inc has been building the world's infrastructure, and in partnership with Caterpillar dealers, is driving positive and sustainable change on every continent. With 2002 sales and revenues of US\$20.15 billion, Caterpillar is the world's leading tnarufacturer of construction and mining equipment, diesel and natural gas engines and industrial gas turbines. The company is a technology leader in construetion, transpontation, mining forestry, energy logistics, electronics, financing and electric power generation.

Allied Engineering and Services Ltd is the Caterpillar dealer for Afghanistan, with over 25 years of experience as a Caterpillar Dealer. Allied has established local presence in Afghanistan to support the sale and service of Caterpilar machines, engines and generator sets. Tajdar Shat is the General Manager with offices in Kabul:

\section{Tadjar Shah}

General Manager

Alied Engineering and Services Lid.

No. 9 Passport Street, Shahr $-\mathrm{Nau}$

Kabul, Afghanistan

Tel: +93.202200287

Mobile: $\$ 9370286211$

Emanil tajdarOaesl.com.pk

Kabul@aeslicom.pk

Web Site: www.Catcon

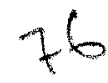


- Power and Electrical Distribution

- Pharmaceutical and Biotechnology

* Housing Lodging Accommodations

Our cooperative structure enables all team members to work together - clients, programproject nanagers, engineers, designers, procurement specialists, health and safety professionals, environmental specialists, construction managers, and maintenance personnel are brought together in a "project tearn" environment which fosters cohesiveness, excellence, and cooperative results on time and within budget. The success of our team is based on the seamless delivery of state-of-the-an core competencies for each of our clients.

VECO has broad experience in successfully completing a variety of federal projects including:

- Our signature project, the EXXON Valdez Ofl Spill Clean Up, prime contractor and program manager on this $\$ 1$ Billion, 12 month fast track project

- The Trans Alaska Pipeline System (Alyeska Pipeline Alliance) providing engineering operations and maintenance services since 1994 for this $800 \mathrm{mile}, 48^{* *}$ oll pipeline

- EPC and O\&M services for the Northstar Offshore Development (Oil \& Gas Production Island)

- Design, construction, and maintenance of the North Early Waming System for the U.S. Air Force

- Design, build, own, and O\&M services for military family housing at Eielson Air Force Base

- Program management and logistics support on a $\$ 25 \mathrm{M}, 5-$ year IDIQ contract for the National Science Fotndation (NSF) on their Arctic research program

Our goal is to add value to every project. Offering integrated engineering, construction, operations and maintenance, and logistics support services, we deliver results with reduced total project schedules, erhanced quality, and overall cost savings.

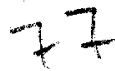


market: self-priming centrifugal trash pumps, submersible pumps, rugged diaphragn pumps, lightweight portable pumps. In the petroleum market, we offer compact high-volume pumps for fvel delivery to aircraf, Roto-Prime pumps for bulk operations, and a wide range of light-weight engine-driven fuel transfer pumps for field operations. Visit our website http//gormanrupp.com . 


\section{Contrack International}

\section{CONIRACK}

Established in 1985, Contrack International, Inc is a $\$ 200+$ Million privately owned and operated U.S. business headquatered in the Washington, D.C. metropolitan area with four regional offices and long-standing affilates around the globe. Over the past two decades, Contrack has steadily increased its revenues as well as expanded its personnel and equipment resources and has been listed as one of the Top International Contractors in the world (as ranked by ENR Magazine) for the last twelve consecutive years. Contrack specializes in large turnkey projects for the US government and private entities worldwide.

In 1997, Contrack created an Engineering Division to ensure the highest levels of control over engineering design, shop drawings and quantity surveying systems. Since it was formed, the Engineering Division has earned a reputation in its own right and now performs a vertety of architectural and enginecring services to Fortune 500 companies as well as Government agencies.

Most recently, Contrack was awarded a project in Afghanistan for the US Army Corps of Engineers. This contract is an Indefinite Delivery/ndefinite Quantity Design/Build project under which work will be performed on a Task Order basis. If all options are exercised, the contract duration will be five years. As a result, Contrack has established a branch office in Kabul. As of today, Contrack has a team of 150 employees and more than $\$ 2,5$ Million worth of equipment including wo concrete batch plants and one asphalt batch plant mobilized in Afghanistan.

Contrack's regional and local offices allow its teams to offer a hands-on management approach that combines international experience with local know-how to develop innovative, workable solutions for clients. Its global presence further helps Contrack establish strong long term relationships with both clients and local communties, ensuring that future projects can be started and completed expeditiously, in a trouble-free enviroment.

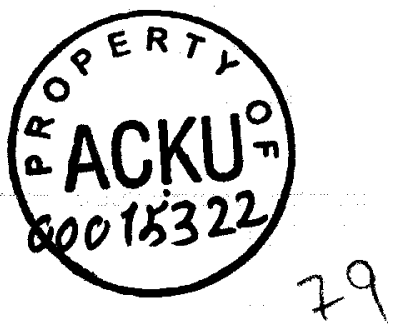

